\title{
CORPORATE RESPONSIBILITY AND FINANCIAL PERFORMANCE: THE ROLE OF INTANGIBLE RESOURCES
}

\author{
JORDI SURROCA, ${ }^{1 *}$ JOSEP A. TRIBÓ, ${ }^{1}$ and SANDRA WADDOCK ${ }^{2}$ \\ 1 Universidad Carlos III de Madrid, Department of Business Administration, Madrid, \\ Spain \\ ${ }^{2}$ Carroll School of Management, Boston College, Chestnut Hill, Massachusetts, U.S.A.
}

\begin{abstract}
This paper examines the effects of a firm's intangible resources in mediating the relationship between corporate responsibility and financial performance. We hypothesize that previous empirical findings of a positive relationship between social and financial performance may be spurious because the researchers failed to account for the mediating effects of intangible resources. Our results indicate that there is no direct relationship between corporate responsibility and financial performance - merely an indirect relationship that relies on the mediating effect of a firm's intangible resources. We demonstrate our theoretical contention with the use of a database comprising 599 companies from 28 countries. Copyright (c) 2009 John Wiley \& Sons, Ltd.
\end{abstract}

\section{INTRODUCTION}

Numerous studies have attempted to identify the relationship between corporate financial performance and corporate social performance. The authors of two recent meta-analyses (Margolis and Walsh, 2003; Orlitzky, Schmidt, and Rynes, 2003) have concluded that the existing empirical evidence supports a modest positive association between these performance measures. Many researchers still claim, however, that much research remains to be conducted before this relationship can be fully understood (e.g., see Griffin and Mahon, 1997; Margolis and Walsh, 2003; Rowley and Berman, 2000; or Wood and Jones, 1995). Specifically, Margolis and Walsh (2003: 278) have stressed the importance of developing models that incorporate omitted variables, test

Keywords: corporate social responsibility; financial performance; intangible resources; stakeholder theory ${ }^{*}$ Correspondence to: Jordi Surroca, Universidad Carlos III de Madrid, Department of Business Administration, Calle Madrid, 126, Getafe, Madrid 28903, Spain.

E-mail: jsurroca@emp.uc3m.es mediating mechanisms and contextual conditions, and establish causal links between social and financial performance.

Some scholars have begun to take steps along these lines. For McWilliams and Siegel (2000), the wide range of contradictory results found in previous literature may be explained by the omission of the variable research and development (R\&D), which generates a misspecification problem. Other scholars indicated that exogenous factors such as the growth of an industry positively moderate the relationship between environmental and economic performance (Russo and Fouts, 1997). Waddock and Graves (1997a) focused on the causality issue, finding that social performance seems to be both a predictor and a consequence of financial results, forming what they called a 'virtuous circle.'

We have drawn upon this research to propose a model in which intangible resources, traditionally perceived to be the basis of a firm's competitive advantage (Barney, 1991; Dierickx and Cool, 1989; Wernerfelt, 1984), may be a missing link that could help explain the relationship between corporate financial performance (CFP) 
and what we term corporate responsibility performance (CRP).

CRP is conceptualized as the broad array of strategies and operating practices that a company develops in its efforts to deal with and create relationships with its numerous stakeholders and the natural environment (Waddock, 2004). CRP reflects the idea that responsibilities are integral to corporate actions, decisions, behaviors, and impacts, whereas the concept of corporate social responsibility connotes the discretionary responsibilities of business (Carroll, 1979).

Adopting this definition of CRP, our study advances the understanding of the relationship between CRP and CFP in three ways: theoretically, empirically, and methodologically. On the theoretical side, we use the resource-based view of the firm (RBV) to extend the literature on stakeholder theory. In particular we propose a model in which firm-based intangible resources, including innovation, human resources, reputation, and organizational culture, are mediator variables between CRP and CFP.

To articulate arguments linking intangibles to both measures of performance, we relied on the RBV framework and especially on its recent formulations connecting social and environmental challenges to firm resources - the so-called natural-resource-based view (Aragón-Correa and Sharma, 2003; Hart, 1995; Russo and Fouts, 1997; Sharma and Vredenburg, 1998). Even though the mainstream RBV focuses on intangibles as a source of competitive advantage, studies adopting the natural view have also supported the notion that intangibles may enhance a firm's responsibility performance (e.g., Aragón-Correa and Sharma, 2003). Researchers have studied intangibles such as innovation (e.g., Klassen and Whybark, 1999), human resources (e.g., Russo and Harrison, 2005), corporate reputation (e.g., Strong, Ringer, and Taylor, 2001), and organizational culture (e.g., Howard-Grenville and Hoffman, 2003) and their links to different dimensions of corporate responsibility. RBV scholars have also noted that the relationship between intangibles and performancewhether financial variables or responsibility variables-may operate in reverse. On the one hand, profitable firms have more opportunities to innovate (e.g., Helfat, 1997) and to make investments for generating human capital (e.g., Wright et al., 2005), reputation (e.g., Roberts and Dowling, 2002), and culture (e.g., Denison, 1990). On the other hand, CRP constitutes an organizational resource that can help firms to develop new intangibles that can be sources of competitive advantages (e.g., Sharma and Vredenburg, 1998).

The main proposition of this paper, which is based on this reasoning, is that intangibles mediate the relationship between CRP and CFP, and that this mediation operates in both causal directions. We hypothesize that there is no direct relationship between CRP and CFP, but that there is a virtuous circle connecting both performance measures through intangibles. Investing in CRP improves intangibles that lead to superior levels of CFP, which in turn must be reinvested in intangibles in order to improve CRP. Further, because other scholars (Russo and Fouts, 1997) have found significant differences in the intangibles of high and low growth industries, we also examine how the growth of the industry influences the strength of the relationships in our model. Accordingly, we argue that firms are more likely to form the virtuous circle when industry growth is high.

Empirically, we use an international database provided by Sustainalytics Responsible Investment Services. It includes information about stakeholder-related performance with respect to employees, communities, suppliers, customers, and environment. Our final sample of 599 firms from 28 nations allows us to overcome the almost exclusive focus on U.S. companies of previous studies and provides robustness to our results.

From a methodological perspective, we use a novel two-stage estimation strategy to determine the relationship between CRP and CFP. A remarkable characteristic of the method is the construction of instruments of the endogenous variables that are independent of the intangibles. By proceeding in this way, our econometric approach addresses endogeneity concerns between the performance variables and allows us to test any direct connection that may exist from CFP to CRP and from CRP to CFP that is not explained by their mutual connection to a firm's intangibles.

\section{EXPLAINING HETEROGENEITY OF RESULTS IN THE CRP-CFP LINK}

Many researchers who have studied the link between CRP and CFP claim that the relationship has not been demonstrated indisputably (Griffin and Mahon, 1997; McWilliams and Siegel, 
2000). ${ }^{1}$ Possible explanations for this lack of consensus rely on drawbacks related to measurement issues (e.g., Griffin and Mahon, 1997), the omission of variables (e.g., McWilliams and Siegel, 2000), and a lack of clear direction of causality between social and financial performance (e.g., Waddock and Graves, 1997a). These drawbacks are discussed in more detail in the next three subsections.

\section{The measurement problem}

Early research on the CRP-CFP link was plagued with measurement problems, because few good measures existed for the multidimensional construct of CRP (Aupperle, Carroll, and Hatfield, 1985; Griffin and Mahon, 1997). These measurement problems have often resulted in what Wood and Jones (1995) termed 'stakeholder mismatching,' as researchers tended to select a single item as a proxy for generic CRP, but one that actually represented only one stakeholder. Recent advances in data collection, particularly the use of the KLD database, have provided broader and more encompassing measures of CRP that have been used in many recent studies (e.g., Hillmam and Keim, 2001). Although these data are far from perfect (e.g., Griffin and Mahon, 1997), they, like the data used in the present study, represent a multidimensional and stakeholder-defined assessment of CRP that is gathered externally by an independent social research firm, and based on a variety of internal and external sources of information, using consistent criteria from year to year.

\section{Misspecification of models}

The meta-analyses of Orlitzky et al. (2003) and Margolis and Walsh (2003) indicate that the wide range of contradictory results found in the literature may be in part attributable to such 'missing elements' as R\&D and advertising (McWilliams and Siegel, 2000), stakeholders' moral values (Schuler and Cording, 2006), or measures of corporate strategy (Berman et al., 1999; Ullman,

\footnotetext{
${ }^{1}$ Although much of the research described in this section has been on corporate social performance (CSP) or corporate social responsibility (CSR), the same arguments apply to the concept of CRP. CRP not only incorporates the discretionary responsibilities of business (CSP or CSR), but also describes how these responsibilities are integrated in any corporate action, decision, behavior, or impact.
}

1985), any of which can mediate or moderate the connection between CRP and CFP (see Rowley and Berman, 2000).

Looking for missing elements requires theoretical models to identify variables that are determinants of performance, but have been omitted in econometric modeling (McWilliams and Siegel, 2000). In such a task, the RBV argues that a firm outperforming its rivals develops distinctive resources that are rare, valuable, inimitable, and not readily substitutable (Barney, 1991). As Sanchez, Chaminade, and Olea (2000) have argued, the only resources that meet these criteria are intangibles; hence we focus in the next sections on specific intangibles that have been associated with competitive advantage.

\section{Direction of causality}

Three views on the direction of causality between CRP and CFP have been tested empirically: 1) the view that stakeholder management (CRP) positively influences CFP, 2) the view that CFP positively influences CRP, and 3) the view defining a recursive relationship between both constructs.

The first research stream, related to instrumental theory (Donaldson and Preston, 1995; Jones, 1995), suggests that CRP influences CFP. The main argument is that good management implies positive relationships with key stakeholders, which in turn improve CFP (Freeman, 1984; Waddock and Graves, 1997a, 1997b). The basic assumption behind this theory, grounded in an RBV logic, is that CRP may be an intangible asset that leads to more effective use of resources (Orlitzky et al., 2003), which has a positive impact on CFP (Hillman and Keim, 2001).

The second strand of literature proposes that CFP influences CRP. The central argument in this literature, called the slack resources hypothesis (Waddock and Graves, 1997a), is that better CFP results in a surplus of resources that provides firms with the financial wherewithal to consider social issues and to do something about them (McGuire, Sundgren, and Schneeweis, 1988).

These two previous streams of research were reconciled by Waddock and Graves (1997a), who suggested that CFP and CRP are synergistic - that CRP is both a predictor and a consequence of CFP, thereby forming a virtuous circle. Financially successful companies can afford to spend more money on social issues, but CRP also helps 
them become financially successful. The metaanalysis of Orlitzky and colleagues (2003) also supported this bidirectional causality, providing evidence that 'both instrumental stakeholder theory and slack resources descriptions are accurate' (Orlitzky et al., 2003: 406).

From this discussion, we can conclude that researchers exploring the CRP-CFP link should simultaneously address the measuring of the CRP construct, the identification of omitted control variables, and the possibility that the causal link may operate in the reverse direction.

\section{HYPOTHESES}

Our research model, which draws upon stakeholder theory and RBV formulations, is grounded on three assumptions: 1) there is a recursive causal link between CRP and CFP (Waddock and Graves, 1997a); 2) various variables may intervene in this bidirectional linkage, supporting an indirect relationship between both performance measures (McWilliams and Siegel, 2000); and 3) the variables intervening in the linkage are the intangibles. Two arguments support the latter assumption. First, it has been argued (Hart, 1995) and empirically tested (Sharma and Vredenburg, 1998) that some corporations respond to calls for environmental protection by developing intangibles that can be sources of competitive advantage; stressing, therefore, the mediating role of intangibles in the association from CRP to CFP. Second, the availability of internal funds is expected to stimulate the development of intangibles, which may be drivers of further improvements in CRP (Shrivastava, 1995a).

Based on these assumptions, we argue that intangibles mediate the connection between social and financial outcomes in both directions. Figure 1 depicts these relationships.

\section{Intangible resources}

The RBV provides us with a useful framework for analyzing the relationship between CRP and CFP for several reasons: 1) the RBV focuses on CFP as the key outcome variable, 2) the RBV presents the possibility of integrating such other outcome variables as CRP, and 3) work adopting this view provides an argument for the interconnection between social and environmental challenges to firm resources.

According to the RBV, differences in firm performance are primarily the consequence of differences in a firm's endowment of resources, especially intangibles, as they are difficult to acquire or develop, to replicate and accumulate, and to be imitated by competitors (Barney, 1991; Dierickx and Cool, 1989; Wernerfelt, 1984). Among possible intangible resources, the firm's technology, human capital, and reputation are considered to be the three of greatest strategic importance (GomezMejía and Balkin, 2002). Other scholars, like Barney (1986) and Grant (1991), have included culture in this group of strategic resources. Empirical

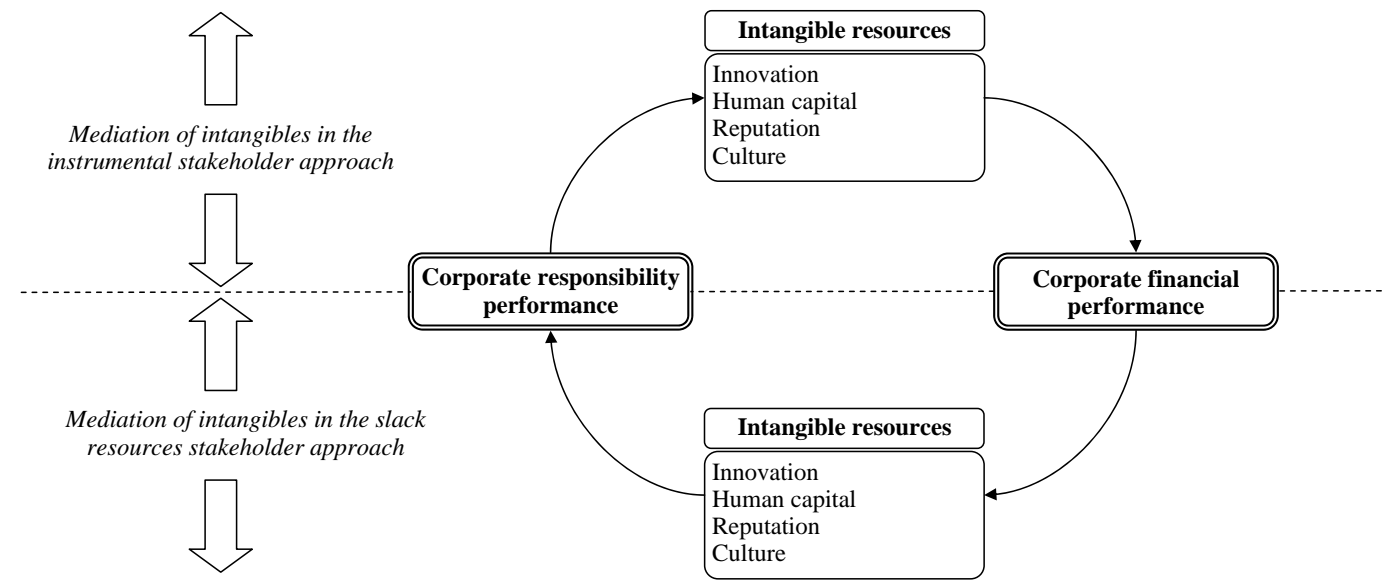

Figure 1. Research model 
research has corroborated the positive influence of innovation (e.g., Cho and Pucik, 2005), human resources (e.g., Huselid, 1995), reputation (e.g., Roberts and Dowling, 2002), and culture (e.g., Marcoulides and Heck, 1993) on the competitiveness of a firm.

Although the RBV is aimed at explaining a firm's competitive advantage and CFP, some studies apply the resource-based logic for explaining how intangibles influence other conceptualizations of corporate performance, like corporate sustainable development (e.g., Bansal, 2005) or environmental performance (e.g., Klassen and Whybark, 1999).

This research has neglected CRP challenges as a source of competitive advantage, however (Hart, 1995). Given the growing importance of social and ecological problems, inserting natural and social concerns into the RBV logic may be helpful for identifying new sources of competitive advantage. The natural RBV of Hart (1995), validated empirically by Sharma and Vredenburg (1998), among others, fills this gap and proposes that social and environmental challenges may lead to the development of organizational intangible resources, which in turn can be sources of competitive advantage.

Such contributions illustrate the potential of the RBV theory as an analytic tool for studying how CRP and CFP are interrelated through their mutual connection to a firm's resources (Russo and Fouts, 1997). To date, however, the potential mediating role of intangibles has been largely overlooked in the literature on the CRP-CFP link. In analyzing such issues, we complement the RBV with the integrative view of stakeholder theory proposed by Waddock and Graves (1997a, 1997b). The complementarities between these theories allow us to analyze the mediating role of intangibles in both causal directions: from CRP to CFP (instrumental approach), and from CRP to CFP (slack resources approach).

\section{The mediating role of intangibles in the instrumental approach}

Drawing upon instrumental stakeholder theory and the natural RBV, we claim that by developing close relationships with primary stakeholders a firm can develop certain intangible resourcestechnology, human resources, reputation, and culture - which enable the most efficient and competitive use of the firm's assets and help it to acquire a competitive advantage over its rivals (e.g., Orlitzky et al., 2003; Sharma and Vredenburg, 1998). Thus, we argue in the following sections that these four intangibles mediate the relationship from CRP to CFP.

Innovation resources. $\mathrm{R} \& \mathrm{D}$ has long been associated with the innovative capacities of firms (e.g., Lichtenberg and Siegel, 1991; Anagnostopoulou and Levis, 2008). This capacity to innovate new products, technologies, and market ideas is strongly influenced by the quality of a firm's relational capital (Thomson and Heron, 2006), which in turn can be enhanced through a proactive social and environmental strategy (Sharma and Vredenburg, 1998). Furthermore, because the capability for generating new technology, products, and improved processes is costly for competitors to copy, innovation can become a source of competitive advantage (Russo and Fouts, 1997; Sharma and Vredenburg, 1998). For example, the adoption of an environmental technology - a best practice of CRP — can be a source of such new product ideas as environmentally friendly products (Shrivastava, 1995a) with enhanced quality and attractiveness, allowing a firm to improve product differentiation and CFP (Hart, 1995; McWilliams and Siegel, 2000, 2001). A firm's environmental policy may also generate process innovations. For example, pollution abatement requires the redesign of a firm's production processes to increase material savings and reduce energy consumption (King and Lennox, 2002; Klassen and Whybark, 1999), thereby increasing the efficiency of the production cycle and reducing production costs (Christmann, 2000). An example of environmental challenges leading to CFP enhancement may be enlightening:

3M discovered that in producing adhesives in batches that were transferred to storage tanks, one bad batch could spoil the entire contents of a tank. The result was wasted raw materials and high costs of hazardous waste disposal. 3M developed a new technique [a process innovation] to run quality tests more rapidly on new batches. The new technique allowed $3 \mathrm{M}$ to reduce hazardous wastes by 10 tons per year at almost no cost, yielding an annual savings of more than $\$ 200,000$ (Porter and ven der Linde, 1995: 102). 
Human resources. Improved CRP also contributes to the accumulation of human resources (HR) or human capital for three reasons. First, those firms perceived to be committed to CRP tend to attract better job applicants and retain them once hired, thereby reducing turnover, recruitment, and training costs (Albinger and Freeman, 2000; Turban and Greening, 1997). Second, CRP also influences work attitudes, favoring employees' morale (Peterson, 2004) and their contribution to initiatives that are beneficial to the organization, such as generating ideas for making corporate practices more environmentally friendly (Ramus and Steger, 2000). Third, the adoption of a proactive environmental strategy leads to the designing of high-commitment HR practices that encourage employee involvement in environmental improvement (Hart, 1995). These practices are: employee empowerment; flexible organizational structures that facilitate the flow of information for identifying solutions to environmental problems; compensation packages to reward employee contributions to CRP improvement; and environmental training programs (Kitazawa and Sarkis, 2000; Rothenberg, Pil, and Maxwell, 2001).

The accumulation of human capital derived from socially responsible practices can become a source of competitive advantage and result in improved financial performance (Becker and Gerhart, 1996; Huselid, 1995; Pfeffer, 1994; Pfeffer and Veiga, 1999). Hart and Milstein support this idea in describing how environmental performance affects profitability through the development of new intangibles related to human resources:

Effective pollution prevention requires extensive employee involvement, along with well-developed capabilities in continuous improvement and quality management.... [Therefore,] with the appropriate set of skills and capabilities (e.g., employee involvement [...]), firms pursuing pollution-prevention and waste-reduction strategies actually do reduce cost and increase profits (Hart and Milstein, 2003: 60; emphasis added).

Reputation. Supporting social performance goals also helps firms to improve both brand and corporate image (Bramer and Pavelin, 2006; Rowley and Berman, 2000), which are important elements of reputation. Beyond achieving a good name for a firm, social responsiveness may influence its stakeholders' judgments, which are the foundation of reputation (Fombrun and Shanley, 1990). As corporate reputations are representations of public opinion about a firm, and as such opinions depend on a firm's success in meeting the expectations of those stakeholders, demonstrating a high degree of CRP is a signal that the firm will behave in accordance with stakeholders' expectations (Bramer and Pavelin, 2006). The firm's reputation will consequently be augmented (Donaldson and Preston, 1995).

Building a positive reputation ensures the continuing participation of stakeholders in corporate activities (Bramer and Pavelin, 2006), which is basic to 'the survival and continuing profitability of the corporation' (Clarkson, 1995: 110). Improved reputations allow firms to attract better employees (Turban and Greening, 1997), augment labor commitment, negotiate better terms with capital suppliers, and build customer loyalty (Fombrun and Shanley, 1990), all of which result in CFP improvements (Fombrun and Shanley, 1990; Roberts and Dowling, 2002). To Hart (1995), BMW is an example of such a process of reputation building through CRP, resulting in an improved competitive position:

In 1990, BMW initiated a 'design-fordisassembly' process... [through which] [b]y acting as the first mover, [the company] was able to capture the few sophisticated German dismantler firms as part of an exclusive recycling infrastructure, thereby gaining a cost advantage over competitors [...]. This move enabled BMW to build an early reputation [...] as a precursor to the introduction of its new line of design-for-environment... automobiles. Once the company had developed and demonstrated the take-back infrastructure through its exclusive BMW dismantlers and disassemblers, executives succeeded in establishing the BMW approach as the German national standard. This move required other car companies to follow $B M W$ 's lead, but at substantially higher costs (Hart, 1995: 995; emphasis added).

Culture. The adoption of a socially responsible strategy can be a source of fundamental changes in business philosophy, decision-making criteria, and ways of working together (Sharma and Vredenburg, 1998). CRP generates a common language 
among organizational actors trying to communicate about social issues, leads members to share routines to develop and implement innovative solutions, and creates formal and informal channels of interaction among stakeholder groups (HowardGrenville and Hoffman, 2003). Thus, by incorporating social considerations into business activities, a firm can develop a culture of innovation and collaborative relationships and mutual trust among stakeholder groups (Russo and Fouts, 1997; Sharma and Vredenburg, 1998).

When social and environmental awareness becomes rooted in the company's culture, CFP improvements follow (Howard-Grenville and Hoffman, 2003). Such improvements can be explained by a socially responsible cultural atmosphere that promotes organizational commitment and learning, cross-functional integration across the organization, increased employee skills, and the incorporation of highly qualified employees (Russo and Fouts, 1997). Consequently, when a firm adopts a strong organizational culture with these characteristics, an increase in financial performance is expected (Barney, 1986; Marcoulides and Heck, 1993; Pfeffer and Veiga, 1999).

Considering the arguments regarding innovation resources, human resources, reputation, and culture, we can state the following hypothesis:

Hypothesis 1a: CRP will have a positive impact on the development of intangibles, which in turn will positively affect CFP. In short, intangibles mediate the relationship from CRP to CFP.

\section{The mediating role of intangibles in the slack resources approach}

The slack resource approach suggests that better financial performance results in more available resources that may be allocated to responsibility activities. We argue that this relationship will be mediated by the firm's intangibles as well.

Innovation resources. The external financing of technological activities is problematic, given the difficulties in the valuation of $R \& D$ projects and the risk of revealing sensitive information about technological activities (Helfat, 1997). Consequently, the availability of internal funds to support R\&D is expected to favor innovation (Nohria and Gulati, 1996). Later, through product innovation, process innovation, or both, a firm may improve its CRP (McWilliams and Siegel, 2001; Klassen and Whybark, 1999). Product innovation allows a firm to incorporate responsible attributes into its goods and services: the redesign and packaging of products in more environmentally responsible ways, for example. Process innovation, on the other hand, enables firms to implement such responsible production practices (McWilliams and Siegel, 2000) as the redesign of manufacturing processes to be less contaminating, the use of less polluting inputs, or the recycling of process byproducts (Christmann, 2000).

Human resources. According to the slack resources argument, high-performing organizations may share profits with employees by developing commitment-based HR practices such as profitsharing schemes, advanced training, team participation, and other forms of empowerment activities (Wright et al., 2005). Apart from the slack resources logic, there are two additional arguments that justify a positive influence of CFP on the development of HR practices (Wright and Gardner, 2002). HR practices serve as an important feedback mechanism for ensuring the future growth of profits, and high-commitment HR practices reduce the risk of future performance declines due to employee lawsuits, unionization, and health and safety fines.

Commitment-based HR practices are an integral part of a firm's social responsiveness toward employees, which is an element of CRP (de la Cruz Déniz-Déniz and De Saá-Pérez, 2003; Liedtka, 1998). Beyond that, employee empowerment, training and team collaboration, and welldesigned reward systems give workers the power, knowledge, and motivation to understand the problems, identify solutions, and implement improved CRP-related practices (Hart, 1995). As one manager explained:

[A]ll of those systems and techniques within [environmental production] remain nothing but a collection of great ideas unless the right people make it happen... We give team members every opportunity to want to care about environmental performance by getting them involved in the decision-making process... The whole key to environmental performance is people (Rothenberg et al., 2001: 239). 
Reputation. In a context of information asymmetries, a firm's reputation is determined by the signals that stakeholders receive about its corporate behavior (Brammer and Pavelin, 2006). Although there are various such signals, investment decisions of external investors, career decisions of employees, and product choices of customers are strongly affected by measures of CFP (Fombrun and Shanley, 1990). Thus, success in the competitive arena signals an effective corporate strategy, good management, and good resource allocations (Roberts and Dowling, 2002).

A positive reputation may also have favorable consequences for stakeholders, leading to higher CRP. If reputation is developed over time as a consequence of the fit between expectations of stakeholders and a firm's behavior (Brammer and Pavelin, 2006), a good reputation will lead stakeholders to believe that the firm will fulfill its ethical responsibilities in the future. Such beliefs should stimulate the formation of trust between stakeholders and the firm, resulting in closer relationships and greater stakeholder satisfaction (Strong et al., 2001).

Culture. Although most of the research suggested that culture improves CFP, the opposite causal model has been upheld (see Saffold, 1988). Culture is not static, but is continuously built and rebuilt because of past successes and failures (Denison, 1990). The case of Medtronic is illustrative. It was the premier firm in the cardiac pacemaker industry in the early 1960s (Denison and Mishra, 1995). Financial success allowed Medtronic's management to stop worrying about external adaptation and to focus all its efforts on the development of its internal processes, thereby creating a humanistic culture of high involvement, commitment, coordination, and identification with core values. But decreased profitability in the mid-1970s led Medtronic's CEO to create a new 'culture' based on bureaucracy, which clearly reduced the involvement of stakeholders and their identification with the firm.

A humanistic culture developed in a situation of high financial gain, may be instrumental in improving CRP. Such a culture promotes good working climate, harmony, trust, and commitment among all its organizational members (Frey and Denison, 2003; Maignan, Ferrell, and Hult, 1999), which in turn enhances stakeholder satisfaction (Maignan et al., 1999). Moreover, by stimulating the cooperation among organizational members, a humanistic culture promotes the employees' search for solutions to reduce the firm's impact on the natural environment (Kitazawa and Sarkis, 2000).

In summary, these arguments lead to the following hypothesis:

Hypothesis 1b: CFP will be positively related to the development of intangibles, which in turn will affect CRP. In short, intangibles mediate the connection from CFP to CRP.

The combination of Hypotheses $1 \mathrm{a}$ and $1 \mathrm{~b}$ lead us to predict that:

Hypothesis 1c. There is no direct relationship between CRP and CFP. Rather, intangibles mediate the relationship between CRP and CFP in both directions.

\section{The mediating role of intangibles in growth sectors}

The majority of work in the RBV tradition has stressed that a firm's competitive advantage is rooted within the firm, in intangibles that are valuable and inimitable; whereas the influence of external factors has been ignored (Barney, 2001). This diagnostic can be extended to the natural RBV of the firm, with some exceptions; Russo and Fouts (1997) concluded, for instance, that profits are more likely to be enhanced through a proactive environmental strategy in high-growth industries than in low-growth ones. Other studies have also provided support for that contention (e.g., Goll and Rasheed, 2004).

Although past studies constitute an advance in understanding the influence of external factors, they have not explicitly incorporated intangibles into research models, and may, therefore, be affected by misspecification problems. An exception is the theoretical work of Aragón-Correa and Sharma (2003), who explained how external factors such as industry growth (a proxy of munificence) affect the linkages among intangibles, CRP, and CFP.

Taking advantage of this contingent approximation to the RBV of the natural environment, we argue that firms in high-growth sectors are more likely than are firms in low-growth sectors to form a virtuous circle connecting CRP and CFP through intangibles. The positive association between CRP 
and CFP in growth industries, as found in Russo and Fouts's (1997) research, is expected to be neutral when intangibles are included as mediators. Such full mediation is expected because industry growth strengthens the association between intangibles and each performance measure, whether CFP or CRP. Next, we discuss the influence of industry growth on the relationships described in Hypothesis 1c.

\section{Forming the virtuous circle through innovation in growth sectors}

The instrumental view. Organizational inertia in the business environment explains why firms in mature stages of the industry life cycle are less likely than are their growing counterparts to obtain innovations from the adoption of best practices of CRP. Such inertia primarily affects firms of mature industries and acts as a barrier to adopting the changes necessary to develop innovative capabilities from CRP strategies (Shrivastava, 1995a, 1995b). In contrast, high-growth industries are populated by firms with organic, nonformalized, and decentralized structures that are less affected by organizational inertia. Such organizational structures facilitate CRP as a source of new ideas (Russo and Fouts, 1997).

Growing industries are also more likely to create a competitive advantage from new inventions, including technological, product, and process innovations. To affect the competitive landscape through the development of new ideas, a company must design operations in smaller decentralized modules, establish organizational structures designed to recognize and assimilate valuable external environmental information, and integrate such information into a firm's procedures and systems (Shrivastava, 1995b). Thus, firms such as high-growth companies with less hierarchical and bureaucratic structures will have a higher prospective return from innovative resources (Russo and Fouts, 1997).

The slack resources view. Agency theory warns that managers may channel slack resources to unproductive investments rather than to productive alternatives like $R \& D$. Those agency problems are especially severe in mature firms with substantial cash and limited growth options (Jensen, 1986). In high-growth industries, in contrast, a firm's survival depends on its capacity to innovate in order to take advantage of growth opportunities. In such a context, slack resources play a crucial role in allowing firms to innovate by permitting them to experiment with new strategies and innovative projects that may not be approved in a more resource-constrained environment (Nohria and Gulati, 1996).

Industry growth also strengthens the association from innovation to CRP (Aragón-Correa and Sharma, 2003). The organic structures of firms in high-growth industries enhance the abilities of organizational members to explore, share, and integrate learning about environmental and social practices across departments and functions, thereby facilitating the accumulation of social and environmental knowledge. This shared knowledge, in combination with the existing technological base of the firm, allows employees to experiment with new ways of coping with unanticipated environmental futures and to develop technologies and new products that incorporate socially desirable properties (Rueda-Manzanares, AragónCorrea, and Sharma, 2008).

\section{Forming the virtuous circle through human resources in growth sectors}

The instrumental view. As noted, CRP contributes to the attraction of better job applicants; to retaining them once hired; and to improving labor morale, attitudes, and loyalty. These outcomes are necessary but not sufficient conditions for developing human capital. It also requires supportive HR practices like employee empowerment, incentive programs, training, and teamwork, in order to encourage employee involvement (Pfeffer and Veiga, 1999). Organic, flexible, and lean organizational structures facilitate the implementation of these commitment-based labor practices (Pfeffer, 1994), and such structures are, as mentioned, more common in growing industries. CRP will therefore be more likely to foster the accumulation of human capital in high-growth industries (Russo and Fouts, 1997).

Furthermore, the accumulation of human capital is vitally important for achieving competitive advantage in rapidly changing industries (Pfeffer, 1994). When the industrial environment is more dynamic, providing a solution to competitive challenges requires collaboration. In such a context, 
commitment-based HR practices and organic structures support the exchange and combination of knowledge among employees to search for solutions (Chatman and Jehn, 1994). Thus the performance effects of such practices are higher in firms belonging to high-growth industries (Lepak, Takeuchi, and Snell, 2003).

The slack resources view. The effect of profits on HR practices is higher in high-growth industries than in mature industries. The predictability and stability of mature environments may lead firms to focus on bureaucratic labor practices. Contrariwise, surviving in rapidly growing environments requires people with expertise in various areas who are motivated to work together to solve nonroutine problems (Chatman and Jehn, 1994). Such requirements explain the importance of spending profits in progressive HR practices that stimulate expertise, collaboration, and motivation (Pfeffer, 1994).

Furthermore, the impact of HR practices on CRP will increase with the industry growth (AragónCorrea and Sharma, 2003). Assuming that people are pivotal to the success of a proactive environmental strategy (Hart, 1995), one would expect that certain organizational structures facilitate employees' activities toward environmental improvements (Shrivastava, 1995a). The search for solutions to environmental challenges requires the reforming, redesigning, and restructuring of companies for implementing HR practices that channel employee efforts toward the minimization of their firm's negative ecological impact (Shrivastava, 1995b). Such restructuring is easier to achieve in high-growth industries than in mature industries (Shrivastava, 1995a), because, as mentioned previously, growing firms are characterized by flexible organizational structures - designs that facilitate pollution prevention efforts (Russo and Fouts, 1997).

\section{Forming the virtuous circle through reputation in growth sectors}

The instrumental view. In mature industries, firms have preexisting, established reputations on numerous dimensions unrelated to social issues (Russo and Fouts, 1997), so the deployment of resources away from core firm's activities (toward CRP activities, for example) may be perceived as wasteful managerial excess, reducing the firm's reputation (Brammer and Pavelin, 2006; Goll and
Rasheed, 2004). Yet, on the contrary, when reputation is still under construction, as it is in growing industries (Russo and Fouts, 1997), demonstrating good social performance helps firms to build social legitimacy and, with that, corporate reputation (Goll and Rasheed, 2004). The growth of a sector, therefore, is expected to strength the relationship between CRP and reputation.

Reputation is relevant primarily for guiding actions under conditions of informational asymmetries between the firm and the public (Fombrun and Shanley, 1990). Thus, firms in high-growth industries will be more likely to reap financial benefits by increasing their reputations (Russo and Fouts, 1997) because the public's level of knowledge of corporate activities is considerably lower in these industries than it is in firms in mature sectors.

The slack resources view. In mature industries, firms often build conglomerates of unrelated product market domains (Chatterjee and Wernerfelt, 1991) - a strategy that impedes the capitalization of synergies and allows the redistribution of resources among divisions (Jensen, 1986). Firms in growth sectors, on the other hand, tend to restrict their focus to one domain (Chatterjee and Wernerfelt, 1991), making profits a more informative signal of a firm's efficiency. Thus, the reputational effect of profits is stronger in more focused firms (Fombrun and Shanley, 1990), such as those in high-growth sectors.

Industry context may influence the effect of reputation on a firm's CRP as well. As the reputation of firms in mature industries is typically dispersed among unrelated domains, any improvement in the reputation of one domain will affect only the expectations of stakeholders with this domain (Mahon, 2002). In high-growth industries, on the other hand, because a firm's business and reputation tend to focus on one domain, or on closely related domains, an improved reputation is more likely to exert a positive influence on the expectations of all the firm's stakeholders and will therefore have a stronger positive impact on CRP. Illustrative are the mature diversifier, Procter \& Gamble (P\&G), and Andersen, a focused company in the high-growth industry of information technology, consulting, and auditing (Mahon, 2002). The Enron problem cost Andersen its good reputation in auditing (and, indeed, its existence), an 
effect that generalized to its closely related consulting business. Yet the problem with Rely-a feminine hygiene product-caused little damage to $P \& G$ 's reputation. Thus, while the incapacity of Andersen to immunize its reputation against the 'Enron problem' destroyed trust between the firm and its stakeholders, Rely's problem 'was with a narrow set of Procter \& Gamble's customers, and it did not impact employees, owners, suppliers, or the larger customer base' (Mahon, 2002: 433).

\section{Forming the virtuous circle through culture in growth sectors}

The instrumental view. CRP may be instrumental in creating a culture around innovativeness and risk taking (Sharma and Vredenburg, 1998), and industry growth favors these links. In growth industries, the unpredictable environment hinders the managerial task of specifying employees' jobs in advance (Chatman and Jehn, 1994; Gordon, 1991). In this context, CRP activities involving employees as well as other stakeholders will channel stakeholders' efforts toward organizational objectives if the firm uses some form of social control. Such social control may be based on a system of values - a culture - that favors risk taking and innovation and instills pride, cooperation, and loyalty among members of the organization (Chatman and Jehn, 1994). In contrast, the influence of CRP on culture is less clear in mature industries that rely on a bureaucratic management style to direct the efforts of organizational members (Russo and Fouts, 1997).

Furthermore, Christensen and Gordon (1999) have found that industry type moderates the relationship between culture and financial performance, suggesting that some cultural traits are successful in one type of industry but unsuccessful in another. In high-growth industries, firms need to develop risk taking and innovation cultures in order to succeed in the marketplace (Gordon, 1991). Hence, industry growth will not only favor the development of this type of innovative culture in socially responsible firms, but will also make it more profitable.

The slack resources view. The case of Medtronic, mentioned previously and described in Denison and Mishra (1995), is illustrative of how the stage of growth in an industry influences the association between CFP and culture. During Medtronic's early years, financial success allowed managers to develop a strong humanistic culture. Several years later, when the industry matured and competition intensified, Medtronic adapted its organization to a more inflexible, hierarchical, and bureaucratic structure and exchanged its humanistic culture for more formal control mechanisms, considerably reducing employee involvement.

As industry growth increases, humanistic cultures that stimulate innovation are more likely to generate prevention efforts (e.g., minimize emissions), thereby improving CRP (Russo and Fouts, 1997). To facilitate pollution prevention, such an innovative culture needs to be accompanied by organizational structures that allow the creation of cross-functional teams of empowered employees who may introduce environmentally friendly changes without excessive management intervention (Kitazawa and Sarkis, 2000). These organic structures are more likely to exist in high-growth industries rather than in mature ones (Chatman and Jehn, 1994).

From the previous arguments, we can hypothesize that:

Hypothesis 2: In high-growth industries, there is no direct relationship between CRP and CFP. Rather, there is a relationship mediated in both directions through intangibles. In such sectors, the mediating role of intangibles is larger than it is in nongrowth sectors.

\section{METHODS}

\section{Sample and data}

Our sample comprises 599 industrial firms included in at least one year of the 2002-2004 Sustainalytics Platform database (before the year 2009 known as SiRi Pro). These data are compiled by the Sustainalytics Responsible Investment Services - the world's largest company specializing in the analysis of socially responsible investment based in Europe, North America, and Australia. Sustainalytics comprises 10 independent research institutions such as KLD, which are coordinated from the Sustainalytics headquarters in Amstersdam, the Netherlands, and Toronto, Canada. For each company, Sustainalytics provides detailed 
profiles of 199 items in collaboration with Sustainalytics national partners. ${ }^{2}$ Using a harmonized methodology, each national partner scrutinizes the social dimensions of the main corporations in its respective home markets. Sustainalytics does not ask companies if they wish to be surveyed, but incorporates them year by year, beginning with the largest companies, to satisfy their objective to cover the largest companies in each home capital market. ${ }^{3}$ The coverage of the S\&P 500, for example, increased from 163 to 196 companies between 2002 and 2004. Information to build these items is extracted from multiples sources, such as financial accounts, company documentation, databases, media reports, interviews with stakeholders, and ongoing contact with managers.

Sustainalytics translates this information into a comprehensive format - a rating - by implementing Likert-type scales and grouping them into eight sections, with one additional section with general information about the company. The first research section provides a description of business ethics. Another section describes corporate governance practices and evaluates whether or not they conform to codes of best practices. The last section measures the degree of involvement in controversial business activities like gambling or alcohol. The remaining five sections cover various issues related to five stakeholder groups: community, customers, employees, suppliers, and environment. For each stakeholder, the database addresses: the level of firm's transparency/disclosure, the existence of corporate policies and principles related to the stakeholder group, the importance of management procedures, and the level of controversies with respect to this stakeholder. Each of these four areas has information items that result in a Likert-type scale score. Importantly, each information item is weighted according to a methodology developed by Sustainalytics. These weights are sector-specific and are developed annually. For each sector, Sustainalytics analysts determine the firm's potential negative impact on each stakeholder and assign a weight in proportion to this potential. Appendix 1 demonstrates some cases

\footnotetext{
${ }^{2}$ Visit www.centreinfo.ch/doc/doc_site/SP-Novartis-06.pdf for an example of a detailed profile, and http://www.sustainalytics.com for more information on Sustainalytics Platform.

${ }^{3}$ In testing for sample selection bias (available upon request), we separated firms by size, and the results comparing both samples were qualitatively the same, thus precluding a size bias in our data.
}

that indicate, for example, that the 'environment' is weighted more heavily for energy companies than it is for companies in the banking industry. The final score provided by Sustainalytics is the sum of each of the scores of the 199 items averaged by its corresponding weight and rated on a scale from zero (worst) to 100 (best).

We complement these data on corporate responsibility with financial data from 2001-2005, extracted from COMPUSTAT Global Vantage. This information allowed us to construct a panel dataset for 599 companies in 28 countries.

\section{Measures}

\section{Corporate responsibility performance}

Sustainalytics Platform rating is used to measure CRP. In addition to providing a final overall rating, the database provides a score for each stakeholder. Consistent with previous studies (e.g., Hillman and Keim, 2001), we consider five stakeholder groups: employees, customers, suppliers, community, and environment. We, therefore measure corporate responsibility performance as the weighted sum of scores of these five stakeholder groups, using the corresponding Sustainalytics weights averaged by sector and country. Note that these dimensions are similar to those from the KLD data used in other research (e.g., Berman et al., 1999).

Although the Sustainalytics and KLD databases both include a multidimensional appraisal of firm responsibility performance, we believe that the Sustainalytics measure of CRP provides answers to the aggregation problems underlined by Graafland, Eijffinger, and Smid (2004), Griffin and Mahon (1997), and Rowley and Berman (2000) with reference to KLD ratings. The problems they identified are threefold. First, individual dimensions of CRP are sometimes uncorrelated, which makes the aggregation of dimensions unrepresentative of a latent variable. Our data do not present this problem given that, for example, the Pearson's correlations for 2003 among the five stakeholders' scores ranged from 0.34 to 0.73 , and all were significant at $p<0.01$. Second, companies in the various sectors are subject to differing circumstances, so would likely treat their stakeholders differentially. As explained, our measure tackles this problem by using sector-specific weights. The authors' third criticism is the treatment of ordinal measures of CRP, such as the KLD index, as if they were 
cardinal. To Graafland et al. (2004), a solution to this problem may be to rely on the judgment of a third party (non-governmental organizations in their case) to weight all CRP dimensions. This is the methodology applied by Sustainalytics to its CRP index, with weights that rely on the judgment of experts. The outcome is an index that can take any value between zero and 100 .

\section{Corporate financial performance}

We use Tobin's $q$ to measure CFP, mainly because of its ability to capture the value of long-term investments like intangible investments, as explained by Dowell, Hart, and Yeung (2000). Like these authors, we proxied Tobin's $q$ by dividing the sum of firm equity value, book value of long-term debt, and net current liabilities by the book value of inventories and property, plant and equipment.

\section{Intangible resources}

Innovation. We measure the intangible of innovation using the ratio of $R \& D$ expenses to a firm's total number of employees. This ratio is 'less sensitive to the spurious effects of business cycles, accounting manipulations, and asset sales than R\&D spending as a proportion of sales' (Baysinger, Kosnik, and Turk, 1991: 207), and is positively related to patents and product innovations (Hitt, Hoskisson, and Kim, 1997).

Human capital. According to Coff (1997), the following human resource practices ultimately contribute to the accumulation of human capital: the measurement of job satisfaction, training programs, profit-sharing programs and employee participation, and the introduction of indicators to seek information about employees. We therefore measure human capital using seven items provided by Sustainalytics that approximate these practices. Each of these items, detailed in Appendix 2, is rated in a five-point Likert scale. Cronbach's alpha for this composite measure is 0.7118 .

Reputation. To measure reputation, we use Fortune magazine's 'World's Most Admired Companies' survey (published annually in a March issue), which extends the methodology of 'America's Most Admired Corporations' to global companies. The survey is based on responses from executives, directors, and financial analysts, and determines a reputation score from eight attributes ranked on 11-point scales from poor to excellent. These attributes are long-term investment value; financial soundness; wise use of corporate assets; community and environmental friendliness; quality of management; product quality; innovativeness; and ability to attract, develop, and keep talented people.

Due to the possible effect of past financial performance on reputation, the so-called halo effect, we regressed reputation on increasingly higher-order lags of CFP until no further significant improvement in $\mathrm{R}^{2}$ was observed (Roberts and Dowling, 2002). We found no significant increases in $\mathrm{R}^{2}$ beyond two lags. We then calculated the residual of reputation as the difference between reputation and the predicted value found in a specification of CFP that included up to two lags of that variable. This residual was our measure of reputation.

Culture. This intangible has four dimensions: involvement, consistency, adaptability, and mission (Denison and Mishra, 1995; Frey and Denison, 2003). We measured these dimensions by using eight Sustainalytics Platform items, defined in a five-point scale. A list of the items is included in Appendix 2. Cronbach's alpha for culture is 0.866 .

\section{Tangible resources and controls}

The management and development of intangible resources is also conditioned by a firm's tangible resources, such as physical assets, leverage, and financial resources.

Physical resources are measured through capital intensity, which is the ratio of total assets minus current assets divided by total assets (Russo and Fouts, 1997); it captures the proportion of 'permanent assets.' Russo and Fouts (1997) obtained a negative effect of this variable on CFP, which is justified because physical assets hinder radical changes on several responsible policies that may boost CFP.

For external financing, we used leverage, which is defined as the accounting value of debt to the accounting value of equity (Waddock and Graves, 1997a). We expected that the higher the value of this ratio, the greater the degree to which management would give preferential attention to creditors at the expense of other stakeholders (Roberts, 
1992: 602-603). Additionally, the impact of leverage on CFP depends on whether or not the positive effect of the reduction in discretionary free cash flows dominates the negative effect on the conflicts of interest between shareholders and debt holders (Jensen, 1986).

We measured financial resources using the cashflow-to-revenues ratio, which approximates the firm's liquidity (Griffin and Mahon, 1997). We hypothesized that the higher the firm's liquidity, the greater the opportunity to invest in new projects that may have a positive social and financial outcome.

Finally, we controlled for size, risk, industry, country, and year. Size was recognized as a determinant of social and financial performance (Ullman, 1985). We approached this variable by the logarithm of the number of employees (e.g., Waddock and Graves, 1997a). Risk and industry have been suggested as factors that affect both social and financial performances (e.g., Waddock and Graves, 1997a). Firm risk is measured with the firm's beta (e.g., Hillman and Keim, 2001), as reported in Global Vantage. Previous studies have noted that there are significant industry (Waddock and Graves, 1997a) and country (Aguilera and Jackson, 2003) effects in the CRP data. There is also a time effect because, as time goes by, more members of the public have access to information about CRP, pressuring firms to invest in responsible practices (Bansal, 2005). We therefore controlled for industry, country, and year by calculating, for each firm, the mean values of the dependent variable for the corresponding country, year, and sector (we adopted the Standard Industrial Classification [SIC] codes of Waddock and Graves, 1997a), excluding the focal firm. ${ }^{4} \mathrm{We}$ included this average as explanatory variable. ${ }^{5}$

\footnotetext{
${ }^{4}$ The percentages by each of the 14 sectors are comparable to those of Waddock and Graves (1997a). Remarkably, our results are robust once we exclude those sectors with the lower (14) or the largest (122) number of firms.

${ }^{5}$ As we explain in the Analysis section, we used fixed-effects models to test our hypotheses. In such models, time-invariant variables are eliminated, so we cannot use sector and country dummies given that firms do not change country and sector over time. Researchers have adopted two interrelated approaches to quantify and control for these effects in fixed-effects estimations. One consists of subtracting the value of the dependent variable averaged by industry, country, and year from each firm's dependent variable (e.g., Ogden and Watson, 1999). The second approach, which we have followed, consists of introducing the averaged dependent variable (excluding the focal firm) as an explanatory variable (Cassiman and Veugelers, 2002).
}

\section{Analysis}

Our mediation hypotheses were tested using an adaptation of the method outlined by Baron and Kenny (1986), the technical details of which are shown in Appendix 3. Baron and Kenny's method consists of the estimation of three regression models. The first model (Model 1 in the Appendix) regresses each of the intangibles (innovation; human capital; reputation, and culture) in terms of CRP and CFP, tangible resources, and controls. The second model (Model 2A in the Appendix) estimates CFP in terms of CRP and controls. The last equation (Model $3 \mathrm{~A}$ in the Appendix) explains CRP in terms of the mediators (intangibles), and the other independent variables.

Regarding our Hypothesis 1a, three conditions must hold in order to establish mediation: 1) CRP must affect intangibles in Model 1, 2) CRP must affect CFP in Model 2A, and 3) intangibles must affect CFP in Model 3A. Mediation holds if the coefficient of CRP, initially significant in Model $2 \mathrm{~A}$, turns out to be nonsignificant when intangibles are included (Model 3A). Our estimating equations for testing Hypothesis $1 \mathrm{~b}$ are formally equivalent to Models 1, 2A, and 3A, but with CFP and CRP interchanged in the last two models. The resulting models are denoted by $2 \mathrm{~B}$ and $3 \mathrm{~B}$.

Our adaptation of the Baron and Kenny's (1986) method consists of refining the estimation of the complete models (Models 3A and 3B) by implementing a two-stage strategy. In the first stage, we construct instruments for CRP and CFP by regressing each performance variable on intangibles and controls, and then computing the residual of each measure of performance by subtracting the predicted effect of intangibles from the dependent variable. In the second stage, we estimate the complete models using such residuals as instruments in order to test the existence of direct effects between the performance variables (Models $3 \mathrm{~A}^{*}$ and $3 \mathrm{~B}^{*}$ ). To control for potential reverse causality, we lag the residual by one period in this second stage. Finally, we estimated these models by using fixed effects.

This estimation strategy has the advantage of tackling problems of multicolinearity and endogeneity. By construction, the residuals of performance will have low correlations with the variables of intangibles thus preventing multicolinearity. Furthermore, by combining the estimation in differences (fixed-effect estimation) with the use 
of instrumental variables (lagged residuals), we addressed both the issues of reverse causality (first endogeneity problem) and the possible correlation between time-invariant unobservable heterogeneity and explanatory variables of performance (second endogeneity problem). The fixed-effect estimation controls for the second endogeneity problem. Additionally, consistency in the fixed-effect estimation requires the reverse causality problem (first endogeneity problem) to be treated by using instruments for the potential endogenous variables (Baltagi, 2003). We have done this by lagging by one period the potential endogenous variable (the residual of the explanatory variable of performance) ${ }^{6}$

Finally, it is a sufficient result for Hypothesis 2 that all these conditions are satisfied only for growth sectors, which are defined as those twodigit SIC code sectors, in which the growth in sales is larger than the yearly mean for all sectors in the corresponding country (Russo and Fouts, 1997). ${ }^{7}$

\section{RESULTS}

Table 1 provides the descriptive statistics for all variables used in the study. Examining the variance inflation factors (VIF), we have found no multicolinearity problems in the data, as VIF values are far from the threshold of 10 . To control for industry influences, we use industry-adjusted measures of each variable by subtracting industry averages from each variable, calculated by excluding the focal firm. Analysis of the correlation matrix lends support to a positive relationship between CFP and

\footnotetext{
${ }^{6} \mathrm{~A}$ good instrument must be correlated with the variable to be measured and uncorrelated with the dependent variable. Panel data allows researchers to use past values of potential endogenous variables to construct such instruments. Lagged variables are, on the one hand, correlated with the potential endogenous variable (because performance variables show some persistence across time) and, on the other hand, have low correlation with the dependent variable. In our case, for example, the instrument of CRP has low correlation with CFP because we use the lagged residual of CRP after eliminating the correlation due to intangibles as an instrument. That approach is similar to and consistent with the generalized method of moments (GMM) technique (Arellano and Bond, 1991), which tackles both endogeneity problems in a dynamic setting by introducing high-order temporal lags as instruments (Wooldridge, 2008). Unfortunately, data on CRP was not available for a sufficient number of years to allow us to use such an econometric method. ${ }^{7}$ Among growth sectors, there are: medicinal chemicals; electronic computers; telephone and telegraph apparatus; semiconductors; TV and radio broadcasting stations; cable and other pay television services.
}

CRP ( $p<0.05)$, a result that is consistent with recent meta-analyses (e.g., Orlitzky et al., 2003). Table 1 also shows positive associations between firm's intangibles and both measures of performance. Thus, we have to undertake a more indepth exploration if the positive link between CRP and CFP could be spurious - simply the result of connections of intangibles with both dimensions of performance.

\section{Tests of hypotheses}

Mediation of intangibles in the instrumental approach (Hypothesis 1a). In Model 1 (available upon request), we find that CRP positively influences innovation $(\beta=0.14 ; p<0.05)$, human capital $(\beta=0.30 ; p<0.01)$, reputation $(\beta=$ $0.38 ; p<0.01)$, and culture $(\beta=0.41 ; p<0.01)$. Furthermore, as shown in Table 2, CRP is positively and significantly related to CFP $(p<0.05)$. This relationship vanishes, however, when we include intangibles as regressors and use the residual of CRP as an instrument. Specifically, Model $3 \mathrm{~A}^{*}$ shows that innovation, human capital, and culture are positively and significantly related to CFP (all at $p<0.01)$, whereas CRP is not $(p>0.10)$. Taken together, these results indicate that innovation, human capital, and culture mediate the relationship between CRP and CFP, providing support for Hypothesis 1a.

Mediation of intangibles in the slack resources approach (Hypothesis 1b). Results for Model 1 (available upon request) indicate that CFP has a positive effect on innovation $(\beta=0.86$; $p<$ $0.01)$, human capital $(\beta=0.53 ; p<0.05)$, reputation $(\beta=0.64 ; p<0.05)$, and culture $(\beta=0.89$; $p<0.05$ ). Results provided in Table 2 (Model $2 B$ ) indicate that CFP has a positive impact on CRP $(p<0.01)$. When intangibles are included in the regression equation (Model 3B*), we find that CFP has no effect on CRP ( $p>0.10)$; whereas innovation $(p<0.05)$, human capital, reputation, and culture (all at $p<0.01$ ) enhance CRP. Thus, the results support Hypothesis 1b, which states that intangibles mediate the relationship from CFP to CRP.

Overall, our findings support the full mediation of intangibles: when they are included in the estimations, any statistically significant relationship between CRP and CFP is no longer significant. These results yield support for our Hypothesis 1c 


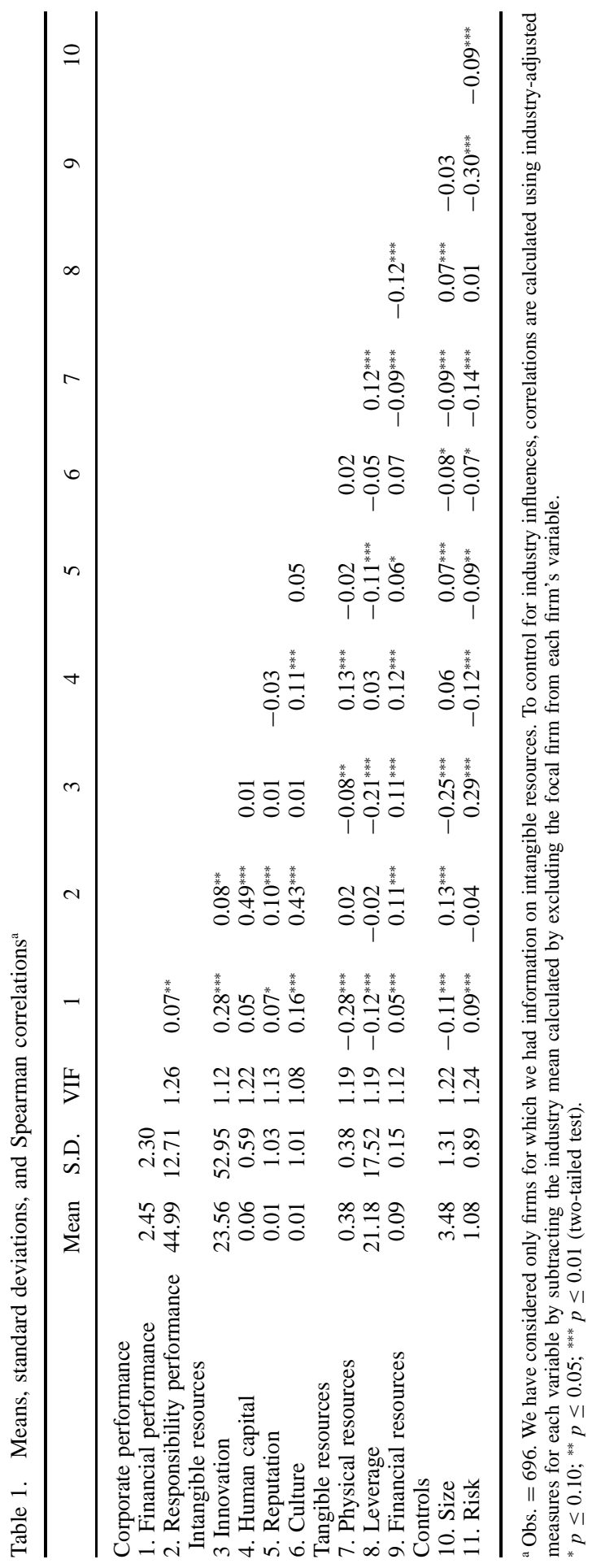


Table 2. Results of fixed-effects regression analyses: full sample

\begin{tabular}{|c|c|c|c|c|}
\hline & \multicolumn{2}{|c|}{$\begin{array}{l}\text { Corporate financial } \\
\text { performance }(\mathrm{CFP})\end{array}$} & \multicolumn{2}{|c|}{$\begin{array}{l}\text { Corporate responsibility } \\
\text { performance }(\mathrm{CRP})\end{array}$} \\
\hline & MODEL 2A & $\overline{\text { MODEL } 3 \mathrm{~A}^{*}}$ & MODEL 2B & MODEL3B* \\
\hline \multicolumn{5}{|l|}{ Corporate performance } \\
\hline CFP & & & $\begin{array}{l}0.6103^{* * *} \\
(0.1260)\end{array}$ & $\begin{array}{c}0.1073 \\
(0.1901)\end{array}$ \\
\hline CRP & $\begin{array}{l}0.0141^{* *} \\
(0.0064)\end{array}$ & $\begin{array}{c}0.0083 \\
(0.0121)\end{array}$ & & \\
\hline \multicolumn{5}{|l|}{ Intangible resources } \\
\hline Innovation & & $\begin{array}{l}0.0306^{* * *} \\
(0.0094)\end{array}$ & & $\begin{array}{c}0.2195^{* *} \\
(0.1151)\end{array}$ \\
\hline Human capital & & $\begin{array}{l}0.0214^{* * * *} \\
(0.0084)\end{array}$ & & $\begin{array}{l}0.3179^{* * *} \\
(0.0366)\end{array}$ \\
\hline Reputation & & $\begin{array}{c}0.0079 \\
(0.0088)\end{array}$ & & $\begin{array}{l}0.0868^{* * *} \\
(0.0302)\end{array}$ \\
\hline Culture & & $\begin{array}{l}0.0143^{* * *} \\
(0.0060)\end{array}$ & & $\begin{array}{l}0.1207^{* * * *} \\
(0.0176)\end{array}$ \\
\hline \multicolumn{5}{|l|}{ Tangible resources } \\
\hline Physical resources & $\begin{array}{l}-0.2099^{* * *} \\
(0.0428)\end{array}$ & $\begin{array}{c}-0.3589^{* * *} \\
(0.0736)\end{array}$ & $\begin{array}{r}-0.1299 \\
(0.1433)\end{array}$ & $\begin{array}{r}-0.3724 \\
(0.2800)\end{array}$ \\
\hline Leverage & $\begin{array}{c}-0.0088 \\
(0.0136)\end{array}$ & $\begin{array}{c}0.0259 \\
(0.0205)\end{array}$ & $\begin{array}{c}0.0545 \\
(0.0515)\end{array}$ & $\begin{array}{r}-0.0147 \\
(0.0681)\end{array}$ \\
\hline Financial resources & $\begin{array}{l}0.0561^{* * *} \\
(0.0109)\end{array}$ & $\begin{array}{l}0.0411^{* * *} \\
(0.0075)\end{array}$ & $\begin{array}{c}0.0198 \\
(0.0230)\end{array}$ & $\begin{array}{l}0.1091^{* *} \\
(0.0539)\end{array}$ \\
\hline \multicolumn{5}{|l|}{ Controls } \\
\hline Size & $\begin{array}{l}-0.1720^{* * *} \\
(0.0404)\end{array}$ & $\begin{array}{r}-0.0939^{*} \\
(0.0569)\end{array}$ & $\begin{array}{l}0.2731^{* *} \\
(0.1461)\end{array}$ & $\begin{array}{r}0.2377^{*} \\
(0.1529)\end{array}$ \\
\hline Risk & $\begin{array}{c}0.0106 \\
(0.0077)\end{array}$ & $\begin{array}{c}0.0225 \\
(0.0204)\end{array}$ & $\begin{array}{c}0.0270 \\
(0.0542)\end{array}$ & $\begin{array}{c}0.0611 \\
(0.0673)\end{array}$ \\
\hline Country, year, sector & $\begin{array}{l}0.0064^{* *} \\
(0.0032)\end{array}$ & $\begin{array}{l}0.0179^{* * *} \\
(0.0053)\end{array}$ & $\begin{array}{l}0.1706^{* * *} \\
(0.0228)\end{array}$ & $\begin{array}{l}0.0963^{* *} \\
(0.0315)\end{array}$ \\
\hline Constant & $\begin{array}{l}0.0232^{* * * *} \\
(0.0062)\end{array}$ & $\begin{array}{c}0.0939 \\
(0.0217)\end{array}$ & $\begin{array}{c}-0.0324 \\
(0.0235)\end{array}$ & $\begin{array}{c}-0.0397 \\
(0.0798)\end{array}$ \\
\hline$R^{2}$ & 0.1106 & 0.3947 & 0.1160 & 0.4188 \\
\hline$F$ test & $12.17^{\text {**** }}$ & $18.76^{* * *}$ & $12.94^{* * *}$ & $25.11^{* * *}$ \\
\hline Number of observations & 1204 & 696 & 1204 & 696 \\
\hline
\end{tabular}

${ }^{a}$ Standardized regression coefficients are shown in the table. Standard deviations are in parentheses.

${ }^{*} p \leq 0.10 ;{ }^{* *} p \leq 0.05 ;{ }^{* * *} p \leq 0.01$ (two-tailed test).

on the existence of a virtuous circle connecting both performance measures through intangibles. Furthermore, inspection of other variables (Models $3 \mathrm{~A}^{*}$ and $3 \mathrm{~B}^{*}$ ) indicates that financial performance increases with financial resources (e.g., Hillman and Keim, 2001) and decreases with physical resources (e.g., Russo and Fouts, 1997) and size (e.g., Hillman and Keim, 2001), whereas financial resources and size improve CRP (e.g., McGuire et al., 1988).

Mediation of intangibles in growth sectors (Hypothesis 2). In unreported estimations for growth sectors (available upon request), we find that CRP is positively and significantly related in Model 1 to innovation resources $(\beta=0.23 ; p<0.05)$, human capital $(\beta=0.25 ; p<0.01)$, reputation $(\beta=0.60 ; p<0.01)$, and culture $(\beta=0.44 ; p<$ $0.01)$; whereas CFP explains innovation $(\beta=$ 1.92; $p<0.01)$, human capital $(\beta=0.60 ; p<$ $0.05)$, reputation $(\beta=1.31 ; p<0.10)$, and culture $(\beta=1.26 ; p<0.01)$. Furthermore, Table 3 indicates that CFP and CRP are related in both directions when the intangibles are not included (Models 2A and 2B). When they are included, the residual of CRP is not related to CFP (Model 3A*) 
Table 3. Results of fixed-effects regression analyses: growth sectors ${ }^{\mathrm{a}}$

\begin{tabular}{|c|c|c|c|c|}
\hline & \multicolumn{2}{|c|}{$\begin{array}{l}\text { Corporate financial } \\
\text { performance (CFP) }\end{array}$} & \multicolumn{2}{|c|}{$\begin{array}{l}\text { Corporate responsibility } \\
\text { performance (CRP) }\end{array}$} \\
\hline & MODEL 2A & MODEL $3 \mathrm{~A}^{*}$ & MODEL 2B & MODEL3B* \\
\hline \multicolumn{5}{|l|}{ Corporate performance } \\
\hline CFP & & & $\begin{array}{l}0.8825^{* * *} \\
(0.2314)\end{array}$ & $\begin{array}{c}0.2883 \\
(0.2696)\end{array}$ \\
\hline CRP & $\begin{array}{l}0.0206^{* *} \\
(0.0092)\end{array}$ & $\begin{array}{c}0.0011 \\
(0.0207)\end{array}$ & & \\
\hline \multicolumn{5}{|l|}{ Intangible resources } \\
\hline Innovation & & $\begin{array}{l}0.0413^{* * *} \\
(0.0078)\end{array}$ & & $\begin{array}{l}0.3763^{* *} \\
(0.1694)\end{array}$ \\
\hline Human capital & & $\begin{array}{l}0.0262^{* * * *} \\
(0.0101)\end{array}$ & & $\begin{array}{l}0.3132^{* * * *} \\
(0.0477)\end{array}$ \\
\hline Reputation & & $\begin{array}{c}0.0089 \\
(0.0085)\end{array}$ & & $\begin{array}{l}0.0965^{* * *} \\
(0.0365)\end{array}$ \\
\hline Culture & & $\begin{array}{l}0.0082^{* *} \\
(0.0039)\end{array}$ & & $\begin{array}{l}0.2068^{* * *} \\
(0.0341)\end{array}$ \\
\hline \multicolumn{5}{|l|}{ Tangible resources } \\
\hline Physical resources & $\begin{array}{l}-0.1966^{* * *} \\
(0.0517)\end{array}$ & $\begin{array}{l}-0.3416^{* * *} \\
(0.1105)\end{array}$ & $\begin{array}{r}-0.0799 \\
(0.2096)\end{array}$ & $\begin{array}{r}-0.0333 \\
(0.3273)\end{array}$ \\
\hline Leverage & $\begin{array}{c}-0.0159 \\
(0.0228)\end{array}$ & $\begin{array}{c}0.0336 \\
(0.0359)\end{array}$ & $\begin{array}{c}0.0431 \\
(0.0858)\end{array}$ & $\begin{array}{c}-0.0163 \\
(0.1174)\end{array}$ \\
\hline Financial resources & $\begin{array}{c}0.0167 \\
(0.0221)\end{array}$ & $\begin{array}{l}0.0752^{* * * *} \\
(0.0170)\end{array}$ & $\begin{array}{c}-0.0197 \\
(0.0457)\end{array}$ & $\begin{array}{c}-0.0261 \\
(0.0738)\end{array}$ \\
\hline \multicolumn{5}{|l|}{ Controls } \\
\hline Size & $\begin{array}{c}-0.0732 \\
(0.0674)\end{array}$ & $\begin{array}{c}0.0468 \\
(0.1583)\end{array}$ & $\begin{array}{c}0.4088 \\
(0.3132)\end{array}$ & $\begin{array}{c}0.4617 \\
(0.3426)\end{array}$ \\
\hline Risk & $\begin{array}{r}0.0200^{*} \\
(0.0116)\end{array}$ & $\begin{array}{c}0.0079 \\
(0.0431)\end{array}$ & $\begin{array}{l}-0.1065 \\
(0.0947)\end{array}$ & $\begin{array}{c}-0.0923 \\
(0.0917)\end{array}$ \\
\hline Country, year, sector & $\begin{array}{l}0.0113^{* * *} \\
(0.0045)\end{array}$ & $\begin{array}{l}0.0172^{* *} \\
(0.0078)\end{array}$ & $\begin{array}{l}0.2016^{* * *} \\
(0.0384)\end{array}$ & $\begin{array}{l}0.1000^{* * * *} \\
(0.0383)\end{array}$ \\
\hline Constant & $\begin{array}{l}0.0432^{* * *} \\
(0.0075)\end{array}$ & $\begin{array}{l}0.1002^{* * *} \\
(0.0335)\end{array}$ & $\begin{array}{c}-0.0125 \\
(0.0302)\end{array}$ & $\begin{array}{c}0.0111 \\
(0.0941)\end{array}$ \\
\hline $\begin{array}{l}R^{2} \\
F_{\text {test }}\end{array}$ & 0.1153 & 0.2969 & 0.1732 & 0.4894 \\
\hline F test & $5.23^{* * * *}$ & $14.56^{* * *}$ & $7.84^{* * * *}$ & $18.63^{* * *}$ \\
\hline Number of observations & 744 & 408 & 744 & 408 \\
\hline
\end{tabular}

${ }^{\text {a }}$ Standardized regression coefficients are shown in the table. Standard deviations are in parentheses. Industry growth is defined as the annual increase in sales. Growth sectors are defined by comparing the industry growth (double-digit SIC code) to the average rate for the corresponding country and year.

${ }^{*} p \leq 0.10 ;{ }^{* *} p \leq 0.05 ;{ }^{* * *} p \leq 0.01$ (two-tailed test).

and the residual of CFP has no effect on CRP (Model 3B*). In addition, Model 3A* shows that innovation, human capital, and culture positively influence CFP (the first two at $p<0.01$ and the latter at $p<0.05$ ); and results for the Model $3 \mathrm{~B}^{*}$ indicate that CRP is explained in terms of innovation $(p<0.05)$ as well as human capital, reputation, and culture (all at $p<0.01$ ), all of which provide evidence that, in high-growth industries, there is no direct relationship between CRP and
CFP, but a relationship mediated in both directions through intangibles. ${ }^{8}$

\footnotetext{
${ }^{8}$ We have also replicated the results separating the sample of growth sectors in terms of firm's size. Such a robustness check addresses a possible criticism that the driver of the results for growth sectors is firm's size given its high correlation with growth $(-35.57 \%)$. The results found (available upon request) are pretty consistent between small firms (whose size is below the median for the corresponding sector year and country) and large ones (above that median) and independently, whether we focus on growth sectors or for the overall sample. This is
} 
Table 4. Results of fixed-effects regression analyses: nongrowth sectors ${ }^{\mathrm{a}}$

\begin{tabular}{|c|c|c|c|c|}
\hline & \multicolumn{2}{|c|}{$\begin{array}{l}\text { Corporate financial } \\
\text { performance (CFP) }\end{array}$} & \multicolumn{2}{|c|}{$\begin{array}{l}\text { Corporate responsibility } \\
\text { performance (CRP) }\end{array}$} \\
\hline & MODEL 2A & MODEL $3 \mathrm{~A}^{*}$ & MODEL 2B & MODEL3B* \\
\hline \multicolumn{5}{|l|}{ Corporate performance } \\
\hline CFP & & & $\begin{array}{l}0.5929^{* * *} \\
(0.2322)\end{array}$ & $\begin{array}{l}0.4529^{* * *} \\
(0.2144)\end{array}$ \\
\hline CRP & $\begin{array}{l}0.0138^{* *} \\
(0.0078)\end{array}$ & $\begin{array}{c}0.0109 \\
(0.0156)\end{array}$ & & \\
\hline \multicolumn{5}{|l|}{ Intangible resources } \\
\hline Innovation & & $\begin{array}{c}0.0451 \\
(0.0555)\end{array}$ & & $\begin{array}{c}0.2075 \\
(0.1870)\end{array}$ \\
\hline Human capital & & $\begin{array}{l}0.0205^{* *} \\
(0.0121)\end{array}$ & & $\begin{array}{l}0.3481^{* * * *} \\
(0.0621)\end{array}$ \\
\hline Reputation & & $\begin{array}{c}0.0163 \\
(0.0153)\end{array}$ & & $\begin{array}{c}0.0694 \\
(0.0446)\end{array}$ \\
\hline Culture & & $\begin{array}{r}0.0148^{*} \\
(0.0085)\end{array}$ & & $\begin{array}{l}0.1175^{* *} \\
(0.0633)\end{array}$ \\
\hline \multicolumn{5}{|l|}{ Tangible resources } \\
\hline Physical resources & $\begin{array}{l}-0.2998^{* * *} \\
(0.0564)\end{array}$ & $\begin{array}{c}-0.3727^{* * *} \\
(0.1275)\end{array}$ & $\begin{array}{r}-0.3352 \\
(0.7936)\end{array}$ & $\begin{array}{c}-0.9574^{* *} \\
(0.5530)\end{array}$ \\
\hline Leverage & $\begin{array}{l}-0.0117 \\
(0.0161)\end{array}$ & $\begin{array}{c}0.0390 \\
(0.0275)\end{array}$ & $\begin{array}{c}0.0723 \\
(0.1337)\end{array}$ & $\begin{array}{c}0.0016 \\
(0.0630)\end{array}$ \\
\hline Financial resources & $\begin{array}{l}0.0438^{* * *} \\
(0.0131)\end{array}$ & $\begin{array}{l}0.0332^{* * *} \\
(0.0085)\end{array}$ & $\begin{array}{c}0.0158 \\
(0.0692)\end{array}$ & $\begin{array}{l}0.2061^{* * * *} \\
(0.0837)\end{array}$ \\
\hline \multicolumn{5}{|l|}{ Controls } \\
\hline Size & $\begin{array}{c}-0.1769^{* *} \\
(0.0776)\end{array}$ & $\begin{array}{c}-0.1312^{* *} \\
(0.0703)\end{array}$ & $\begin{array}{l}0.4602^{* *} \\
(0.2564)\end{array}$ & $\begin{array}{l}0.3035^{* *} \\
(0.1044)\end{array}$ \\
\hline Risk & $\begin{array}{c}0.0307 \\
(0.0177)\end{array}$ & $\begin{array}{c}0.0365 \\
(0.0293)\end{array}$ & $\begin{array}{c}0.0840 \\
(0.1370)\end{array}$ & $\begin{array}{r}0.1403^{*} \\
(0.0875)\end{array}$ \\
\hline Country, year, sector & $\begin{array}{l}0.0020 \\
(0.0078)\end{array}$ & $\begin{array}{l}0.0279^{* * * *} \\
(0.0077)\end{array}$ & $\begin{array}{l}0.1216^{* * *} \\
(0.0485)\end{array}$ & $\begin{array}{c}0.0373 \\
(0.0292)\end{array}$ \\
\hline Constant & $\begin{array}{l}0.0713^{* * *} \\
(0.0147)\end{array}$ & $\begin{array}{l}0.0713^{* *} \\
(0.0402)\end{array}$ & $\begin{array}{r}-0.1670 \\
(0.8977)\end{array}$ & $\begin{array}{r}-0.1660 \\
(0.1518)\end{array}$ \\
\hline$R^{2}$ within & 0.1550 & 0.2381 & 0.1305 & 0.5364 \\
\hline$F$ test & $3.73^{* * *}$ & $4.78^{* * *}$ & $2.57^{* *}$ & $12.51^{* * *}$ \\
\hline Number of observations & 460 & 288 & 460 & 288 \\
\hline
\end{tabular}

${ }^{a}$ Standardized regression coefficients are shown in the table. Standard deviations are in parentheses. Industry growth is defined as annual increase in sales. Nongrowth sectors are defined by comparing the industry growth (double-digit SIC code) to the average rate for the corresponding country and year.

${ }^{*} p \leq 0.10 ;{ }^{* *} p \leq 0.05 ;{ }^{* * *} p \leq 0.01$ (two-tailed test).

To explore further whether industry growth strengthens the virtuous circle, we compared these findings with those for nongrowth sectors (see

evidence that although there are smaller firms in growth sectors, this is not the driver that explains the results found. Similar robustness evidence is found once we separate the sample of growth sectors in terms of firm's age (available upon request), eliminating the suspicion that the driver of the results in growth sectors is that firms in such sectors are younger (although the correlation between age and growth is only $-5.49 \%$ in our sample).
Table 4). Results for mature industries show that the mediation of intangibles is weaker than for their growing counterparts. In particular, results for Model 1 (available upon request), indicate that, while CRP is a significant variable explaining all of a firm's intangibles - but at a lower significant levels than in growth sectors-, CFP has only a positive effect on innovation and human capital. Furthermore, an examination of Models 3A* and $3 \mathrm{~B}^{*}$ shows that only human capital and culture have positive and significant influences on 
both CRP and CFP. Such evidence for nongrowth sectors suggests that the virtuous circle connecting CRP and CFP operates through only one intangible: human capital. ${ }^{9}$ Meanwhile, in high-growth industries, innovation and culture, in addition to human capital, mediate the relationship between CFP and CRP in both directions, providing support to Hypothesis 2.

\section{DISCUSSION AND CONCLUSIONS}

We have investigated the connection between CRP and CFP, exploring the role that intangibles play in mediating that relationship. Although recent metaanalyses have suggested that the CRP-CFP relationship is somewhat positive, many researchers still claim that further work is needed to clarify the way in which CFP and CRP should be operationalized, the direction of causality, or the omitted variables that intervene in the CRP-CFP linkage. Hence, the debate is open, and new models that give responses to these concerns are needed. This research provides an explanation for the CRPCFP interface by analyzing the role of intangible resources.

\section{Intangibles and performance}

We argue that researchers have not considered the intervention of a firm's intangibles in the CRPCFP linkage. RBV scholars have underlined the importance of intangibles as determinants of performance and this study extends that line of thinking. Drawing upon the natural RBV (Hart, 1995) and stakeholder theories, arguments were developed in this study to explain that profitable and socially responsible firms are capable, more so than irresponsible firms, of generating intangibles such as innovation, human capital, reputation, and culture. Hence, we hypothesized that intangibles mediate the relationship between CFP and CRP in

\footnotetext{
${ }^{9}$ There is no virtuous circle through culture because of the null effect of CFP on this intangible. An explanation of the importance of employees in improving both CRP and CFP in mature industries can be derived from the study of Jawahar and McLaughlin (2001). According to these authors, mature firms are often risk averse, characterized by excessive cash and low investment opportunities. In this context, mature firms, which generally have a well-defined culture and reputation, can be proactive only in enhancing CRP by spending resources in training and development activities, and implementing incentive programs for their employees.
}

both directions, giving rise to a virtuous circle that moves back and forth from CRP to CFP through investments in intangibles.

To test this hypothesis, we used the Sustainalytics Platform database, which allowed us to construct an index of CRP with clear advantages over other options, such as its international content, its multidimensional appraisal of a firm's CRP, and its weighting scheme, which makes Sustainalytics' CRP scores close to cardinal measures facilitating comparisons among firms in different sectors. Concerning the econometric approach, we used a two-stage estimation that corrects for endogeneity concerns and for spurious correlations between both performance variables.

Proceeding in this way, we found that CRP stimulates the development of intangibles related to innovation, human capital, reputation, and culture, which lead in turn to improved financial outcomes. Our results also support the opposite causal chain. Hence, there is no direct relationship between CRP and $\mathrm{CFP}$ - merely an indirect relationship mediated by a firm's intangibles. We interpret these findings in terms of a virtuous circle, in which any increase in one type of performance is translated into an improvement in the other, if and only if new intangibles are developed. Finally, we found the mediation of intangibles to be stronger in growth industries than in nongrowth industries. This finding further demonstrates the robustness of our research model, as previous researchers (e.g., Russo and Fouts, 1997) expected a strong direct linkage between CRP and CFP in growth sectors rather than a mediated relationship.

\section{Implications for research}

An explanation for the dispersion of results. Wood and Jones (1995) attributed the wide range of research results to a mismatch between CRP measurements and CFP. In our case, we developed the misspecification logic of McWilliams and Siegel (2000), proposing that these positive relationships between variations of CFP and CRP may be spurious, and simply the result of variations in intangibles. Our model also explains the neutral or negative relationships between CFP and CRP in previous studies (e.g., Hillman and Keim, 2001, for social issue participation as a proxy of CRP). When performance does not develop intangible resources or, worse, destroys them, neutral or negative associations may emerge. Our study therefore 
emphasizes the importance of including intangibles like innovation, human capital, reputation, and culture in further studies of CFP-CRP linkages. Failure to control for these intangibles may explain some of the mixed findings that have occurred in the past.

The virtuous circle: $R B V$ and stakeholder theory formulations. Our results have reinforced RBV theories of the firm by highlighting the importance of intangibles to explain differentials in both CFP and CRP. Furthermore, we have contributed to an explanation about the way in which intangibles are created and developed, specifically through our finding that CFP and CRP are determinants of this creation. Slack resources allow firms to invest in resources and capabilities that are necessary for successful adaptation to internal pressures for adjustment or to external pressures for change. In addition, investing in responsible activities develops a capability for generating new products and improved processes, which has important consequences for employee motivation and morale, and is instrumental in creating high-commitment and participative cultures.

This research also enriches the stakeholder literature. We posit that stakeholder management alone is not a means for achieving financial success and, conversely, that better CFP does not lead to better CRP. The development of intangibles is the key factor in improving both financial and responsibility performance, forming the virtuous cycle.

The influence of contextual conditions. Results of this research suggest that both the firm's capacity to generate intangible resources and the capability of these resources to improve performance are determined in the interplay with market forces. Specifically, we have provided evidence for the importance of the growth of an industry, showing that firms are more likely to form a virtuous circle connecting CRP and CFP through intangibles in high-growth industries, where some scholars (e.g., Russo and Fouts, 1997) expected a stronger direct linkage from CRP to CFP. One could interpret these data to mean that forming such a virtuous circle requires decentralized organizations that are more likely to be formed in high-growth business environments (Aragón-Correa and Sharma, 2003).

\section{Implications for practice}

We suggest, congruently with the RBV, that managers need to turn their attention to the efficient management of a firm's intangible resources, particularly its innovation, human capital, reputation, and culture, which are difficult resources for competitors to match.

Where to place investments? To improve stakeholder satisfaction, managers can invest slack resources in those activities that improve a firm's intangibles. There are various critical factors toward which investments should be placed in order to improve socially responsible outcomes, including programs to improve organization culture and generate greater loyalty among employees, human resource practices that improve employee involvement and increase job attractiveness, investments in technology that facilitate product and process innovation, and credible reputation-building activities.

To improve shareholder value, managers must learn that markets value socially responsible companies if they accompany such activities with investments in intangibles that ensure the sustainability of socially responsible policies. On the other hand, irresponsible CRP that cut costs in order to improve CFP (e.g. activities in countries with human rights abuses) may generate the opposite effect. Such practices have negative consequences on intangibles; they destroy employee loyalty and corporate culture and negatively affect external reputation and internal innovations. Intangibles are, therefore, the key elements that allow the virtuous circle of value creation to work along time.

How can the virtuous circle work through incentive setting? Given that managers' interests are not always oriented toward the adequate management of intangibles, an effective incentive scheme should align the interests of managers with investments in intangibles if the virtuous circle is to work. Based on results demonstrating that both responsibility and financial performances are linked to intangible resource management, the prescription is to link managerial compensation to both CFP and CRP. This proposal is not free of criticism because such a design requires solid measures of CRP in order to compensate adequately those managerial efforts favoring stakeholder- 
related activities (Tirole, 2001). We believe that measures like the Sustainalytics score will soon tackle this problem.

\section{Limitations and future research}

Qualifying these conclusions, we recognize some weaknesses in our study. First, although we believe that the Sustainalytics database improves the measurement of CRP, it is not free from criticism. The CRP index of Sustainalytics aggregates multiple social dimensions, for example, with no theoretical basis for assuming that they are correlated (Waddock and Graves, 1997a; Rowley and Berman, 2000). Our measures of some of the intangible resources could be seen as another limitation. Several scholars have measured culture through the organizational culture profile (O'Reilly, Chatman, and Caldwell, 1991) or innovation resources through number of patents, product/process innovations, or scientists - although Hitt et al. (1997) have demonstrated that $R \& D$ intensity is positively related to these other proxies. Furthermore, we have not considered in our research model the possibility that other variables could intervene in the associations among CRP, intangibles, and CFP. It is possible, for example, that other dimensions of the business environment (e.g., uncertainty [Aragón-Correa and Sharma, 2003], or degree of competition [Bagnoli and Watts, 2003]) moderate the causal links among our model variables. An exploration of these issues will be the subject of future research.

\section{ACKNOWLEDGEMENTS}

The authors thank Carlos Bendito, business development and institutional banking director of Triodos Bank N.V. S.E., for his helpful comments and for access to the Sustainalytics Platform database. We also like thank Pascual Berrone, Luis GomezMejia, Sam Graves, Isabel Gutiérrez, the SMJ referees and editor, as well as conference participants at the Academy of Management (Honolulu, 2005), the Strategic Management Society (Orlando, 2005), and the European Academy of Management (Munich, 2005) for valuable comments and suggestions on earlier drafts. Financial support of the Comunidad de Madrid (Grants \# 2008/00037/001, \# 2009/00138/001 and S2007/
HUM-0413), Fundación Ramón Areces, and Ministry of Education and Science (Grants \# SEJ200601731, \# SEJ2006-09401, \# CSD 2006-16, ECO 2009-10796, and ECO2009-08308) is gratefully acknowledged. The usual disclaimers apply.

\section{REFERENCES}

Aguilera RV, Jackson G. 2003. The cross-national diversity of corporate governance: dimensions and determinants. Academy of Management Review 28(3): 447-465.

Albinger HS, Freeman SJ. 2000. Corporate social performance and attractiveness as an employer to different job seeking populations. Journal of Business Ethics 28: $243-253$.

Anagnostopoulou SC, Levis M. 2008. R\&D and performance persistence: evidence from the United Kingdom. International Journal of Acccounting 43(3): 293-320.

Aragón-Correa JA, Sharma S. 2003. A contingent resource-based view of proactive corporate environmental strategy. Academy of Management Review 28(1): 71-88.

Arellano M, Bond S. 1991. Some tests of specification for panel data: Monte Carlo evidence and an application to employment equations. Review of Economic Studies 58: $277-294$.

Aupperle K, Carroll A, Hatfield J. 1985. An empirical examination of the relationship between corporate social responsibility and profitability. Academy of Management Journal 28(2): 446-463.

Bagnoli M, Watts S. 2003. Selling to socially responsible consumers: competition and the private provision of public goods. Journal of Economics and Management Strategy 12: 419-445.

Baltagi BH. 2003. Econometric Analysis of Panel Data. Wiley: New York.

Bansal P. 2005. Evolving sustainably: a longitudinal study of corporate sustainable development. Strategic Management Journal 26(3): 197-218.

Barney J. 1986. Organizational culture: can it be a source of sustained competitive advantage? Academy of Management Review 11(3): 656-665.

Barney J. 1991. Firm resources and sustained competitive advantage. Journal of Management 17(1): 771-792.

Barney JB. 2001. Resource-based theories of competitive advantage: a ten year retrospective on the resourcebased view. Journal of Management 27: 643-650.

Baron R, Kenny D. 1986. The moderator-mediator variable distinction in social psychological research: conceptual, strategic and statistical considerations. Journal of Personality and Social Psychology 51: 1173-1182.

Baysinger BD, Kosnik RD, Turk TA. 1991. Effects of board and ownership structure on corporate R\&D strategy. Academy of Management Journal 34(1): 205-214.

Becker B, Gerhart B. 1996. The impact of human resource management on organizational performance: 
progress and prospects. Academy of Management Journal 39(4): 779-801.

Berman S, Wicks A, Kotha S, Jones T. 1999. Does stakeholder orientation matter? The relationship between stakeholder management models and firm financial performance. Academy of Management Journal 42(5): 488-506.

Brammer SJ, Pavelin S. 2006. Corporate reputation and social performance: the importance of fit. Journal of Management Studies 43(3): 435-455.

Carroll AB. 1979. A three-dimensional conceptual model of corporate social performance. Academy of Management Review 4(1): 497-505.

Cassiman B, Veugelers R. 2002. R\&D cooperation and spillovers: some empirical evidence from Belgium. American Economic Review 92(4): 1169-1184.

Chatman JA, Jehn KA. 1994. Assessing the relationship between industry characteristics and organizational culture: how different can you be? Academy of Management Journal 37(3): 522-553.

Chatterjee S, Wernerfelt B. 1991. The link between resources and type of diversification: theory and evidence. Strategic Management Journal 12(1): 33-48.

Cho H, Pucik V. 2005. Relationship between innovativeness, quality, growth, profitability, and market value. Strategic Management Journal 26(6): 555-575.

Christensen EW, Gordon GG. 1999. An exploration of industry, culture, and revenue growth. Organization Studies 20(3): 397-422.

Christmann P. 2000. Effects of 'best practices' of environmental management on cost advantage: the role of complementary assets. Academy of Management Journal 43(4): 663-680.

Clarkson MBE. 1995. A stakeholder framework for analyzing and evaluating corporate social performance. Academy of Management Review 20(1): 92-117.

Coff RW. 1997. Human assets and management dilemmas: coping with hazards on the road to resource-based theory. Academy of Management Review 22(2): 374-402.

de la Cruz Déniz-Déniz M, De Saá-Pérez P. 2003. A resource-based view of corporate responsiveness toward employees. Organization Studies 24(2): 299-320.

Denison DR. 1990. Corporate Culture and Organizational Effectiveness. Wiley: New York.

Denison DR, Mishra AK. 1995. Toward a theory of organizational culture and effectiveness. Organization Science 6(2): 204-223.

Dierickx I, Cool K. 1989. Asset stock accumulation and sustainability of competitive advantage. Management Science 35: 1504-1511.

Donaldson TL, Preston LE. 1995. The stakeholder theory of the corporation: concepts, evidence, and implications. Academy of Management Review 20(1): 65-91.

Dowell G, Hart S, Yeung B. 2000. Do corporate global environmental standards create or destroy market value? Management Science 46(8): 1059-1074.
Fombrun C, Shanley M. 1990. What's in a name? Reputation building and corporate strategy. Academy of Management Journal 33(2): 233-258.

Freeman RE. 1984. Strategic Management: A Stakeholder Approach. Pitman: Boston, MA.

Frey CF, Denison DR. 2003. Organizational culture and effectiveness: can American theory be applied in Russia? Organization Science 14(6): 686-706.

Goll I, Rasheed AA. 2004. The moderating effect of environmental munificence and dynamism on the relationship between discretionary social responsibility and firm performance. Journal of Business Ethics 49: $41-54$

Gomez-Mejia LR, Balkin DB. 2002. Management. McGraw-Hill: New York.

Gordon GG. 1991. Industry determinants of organizational culture. Academy of Management Review 16(2): $396-415$.

Graafland JJ, Eijffinger SCW, Smid H. 2004. Benchmarking of corporate social responsibility: methodological problems and robustness. Journal of Business Ethics 53: 137-152.

Grant RM. 1991. The resource-based theory of competitive advantage. California Management Review 33(3): 114-135.

Griffin JJ, Mahon JF. 1997. The corporate social performance and corporate financial performance debate. twenty-five years of incomparable research. Business and Society 36(1): 5-31.

Hart SL. 1995. A natural resource-based view of the firm. Academy of Management Review 20(4): 986-1014.

Hart SL, Milstein MB. 2003. Creating sustainable value. Academy of Management Executive 17(2): 56-69.

Helfat C. 1997. Know-how and asset complementarity and dynamic capability accumulation: the case of R\&D. Strategic Management Journal 18(5): 339-360.

Hillman AJ, Keim GD. 2001. Shareholder value, stakeholder management, and social issues: what's the bottom line? Strategic Management Journal 22(2): $125-139$.

Hitt MA, Hoskisson RE, Kim H. 1997. International diversification: effects on innovation and firm performance in product-diversified firms. Academy of Management Journal 40(4): 767-798.

Howard-Grenville JA, Hoffman AJ. 2003. The importance of cultural framing to the success of social initiatives in business. Academy of Management Executive 17(2): 70-84.

Huselid MA. 1995. The impact of human resource management practices on turnover, productivity, and corporate financial performance. Academy of Management Journal 38(3): 635-672.

Jawahar IM, McLaughlin GL. 2001. Toward a descriptive stakeholder theory: an organizational life cycle approach. Academy of Management Review 26(3): $397-414$

Jensen MC. 1986. Agency costs of free cash flow, corporate finance, and ownership structure. American Economic Review 76: 323-329.

Jones TM. 1995. Instrumental stakeholder theory: a synthesis of ethics and economics. Academy of Management Review 20(2): 404-437. 
King A, Lenox M. 2002. Exploring the locus of profitable pollution reduction. Management Science 48(2): 289-299.

Kitazawa S, Sarkis J. 2000. The relationship between ISO 14001 and continuous source reduction programs. International Journal of Operations \& Production Management 20(2): 225-248.

Klassen RD, Whybark DC. 1999. The impact of environmental technologies on manufacturing performance. Academy of Management Journal 42(6): 599-615.

Lepak DP, Takeuchi R, Snell SA. 2003. Employment flexibility and firm performance: examining the interaction effects of employment mode, environmental dynamism, and technological intensity. Journal of Management 29(5): 681-703.

Lichtenberg F, Siegel D. 1991. The impact of R\&D investment on productivity: new evidence using linked R\&D-LRD data. Economic Inquiry 29: 203-228.

Liedtka JM. 1998. Constructing an ethic for business practice: competing effectively and doing good. Business and Society 37(3): 254-280.

Mahon JF. 2002. Corporate reputation: a research agenda using strategy and stakeholder literature. Business and Society 41(4): 415-445.

Maignan I, Ferrell OC, Hult GTM. 1999. Corporate citizenship: cultural antecedents and business benefits. Journal of the Academy of Marketing Science 27(4): 455-469.

Marcoulides GA, Heck RH. 1993. Organizational culture and performance: proposing and testing a model. Organization Science 4(2): 209-225.

Margolis JD, Walsh JP. 2003. Misery loves companies: rethinking social initiatives by business. Administrative Science Quarterly 48(2): 268-305.

McGuire JB, Sundgren A, Schneeweis T. 1988. Corporate social responsibility and firm financial performance. Academy of Management Journal 31(4): $854-872$.

McWilliams A, Siegel D. 2000. Corporate social responsibility and financial performance: correlation or misspecification? Strategic Management Journal 21(5): 603-609.

McWilliams A, Siegel D. 2001. Corporate social responsibility: a theory of the firm perspective. Academy of Management Review 26(1): 117-127.

Nohria N, Gulati R. 1996. Is slack good or bad for innovation? Academy of Management Journal 39(5): 1245-1264.

Ogden S, Watson R. 1999. Corporate performance and stakeholder management: balancing shareholder and customer interests in the UK privatized water industry. Academy of Management Journal 42(5): 526-538.

O'Reilly CA, Chatman J, Caldwell DF. 1991. People and organizational culture: a profile comparison approach to assessing person-environment fit. Academy of Management Journal 34(3): 487-516.

Orlitzky M, Schmidt FL, Rynes SL. 2003. Corporate social and financial performance: a meta-analysis. Organization Studies 24(3): 403-441.

Peterson DK. 2004. The relationship between perceptions of corporate citizenship and organizational commitment. Business and Society 43(3): 296-319.
Pfeffer J. 1994. Competitive Advantage through People: Unleashing the Power of the Work Force. Harvard Business School Press: Boston, MA.

Pfeffer J, Veiga JF. 1999. Putting people first for organizational success. Academy of Management Executive 13(2): 37-48.

Porter ME, van der Linde C. 1995. Toward a new conception of the environment-competitiveness relationship. Journal of Economic Perspectives 9(4): 97-118.

Ramus CA, Steger U. 2000. The roles of supervisory support behaviors and environmental policy in employee 'ecoinitiatives' at leading-edge European companies. Academy of Management Journal 43(4): 605-626.

Roberts PW, Dowling GR. 2002. Corporate reputation and sustained superior financial performance. Strategic Management Journal 23(12): 1077-1093.

Roberts R. 1992. Determinants of corporate social responsibility disclosure: an application of stakeholder theory. Accounting, Organizations and Society 17(6): 595-612.

Rothenberg S, Pil FK, Maxwell J. 2001. Lean, green, and the quest for superior environmental performance. Production and Operations Management 10(3): 228-243.

Rowley T, Berman S. 2000. A brand new brand of corporate social performance. Business and Society 39(4): 397-418.

Rueda-Manzanares JA, Aragón-Correa A, Sharma S. 2008. The influence of stakeholders on the environmental strategy of service firms: the moderating effects of complexity, uncertainty and munificence. British Journal of Management 19(2): 185-203.

Russo MV, Fouts PA. 1997. A resource-based perspective on corporate environmental performance and profitability. Academy of Management Journal 40(3): 534-559.

Russo MV, Harrison NS. 2005. Organizational design and environmental performance: clues from the electronics industry. Academy of Management Journal 48(4): 582-593.

Saffold GS III. 1988. Culture traits, strength, and organizational performance: moving beyond 'strong' culture. Academy of Management Review 13(4): 546-558.

Sanchez P, Chaminade C, Olea M. 2000. Management of intangibles: an attempt to build theory. Journal of Intellectual Capital 1(4): 312-327.

Schuler DA, Cording M. 2006. A corporate social performance-corporate financial performance behavioral model for consumers. Academy of Management Review 31(3): 540-558.

Sharma S, Vredenburg H. 1998. Proactive corporate environmental strategy and the development of competitively valuable organizational capabilities. Strategic Management Journal 19(8): 729-753.

Shrivastava P. 1995a. Environmental technologies and competitive advantage. Strategic Management Journal, Summer Special Issue 16: 183-200.

Shrivastava P. 1995b. The role of corporations in achieving ecological sustainability. Academy of Management Review 20(4): 936-960. 
Strong KC, Ringer RC, Taylor SA. 2001. THE* ruled of stakeholder satisfaction (*timeliness, honesty, empathy). Journal of Business Ethics 32(3): 219-230.

Thomson M, Heron P. 2006. Relational quality and innovative performance in R\&D based science and technology firms. Human Resource Management Journal 16(10): 28-47.

Tirole J. 2001. Corporate governance. Econometrica 69(1): $1-35$.

Turban DB, Greening DW. 1997. Corporate social performance and organizational attractiveness. Academy of Management Journal 40(3): 658-672.

Ullman A. 1985. Data in search of a theory: a critical examination of the relationship among social performance, social disclosure and economic performance of U.S. firms. Academy of Management Review 10(1/2): 540-557.

Waddock SA. 2004. Parallel universes: companies, academics, and the progress of corporate citizenship. Business and Society Review 109(1): 5-42.

Waddock SA, Graves SB. 1997a. The corporate social performance-financial performance link. Strategic Management Journal 18(4): 303-319.
Waddock SA, Graves SB. 1997b. Quality of management and quality of stakeholder relationships: are they synonymous? Business \& Society 36(3): 250-279.

Wernerfelt B. 1984. A resource-based view of the firm. Strategic Management Journal 5(2): 171-180.

Wood DJ, Jones RE. 1995. Stakeholder mismatching: a theoretical problem in empirical research on corporate social performance. International Journal of Organizational Analysis 3(3): 229-267.

Wooldridge JM. 2008. Econometric Analysis of Cross Section and Panel Data (2nd edn). MIT press: Cambridge, MA.

Wright PM, Gardner TM. 2002. The human resourcefirm performance relationship: methodological and theoretical challenges. In The New Workplace: A Guide to the Human Impact of Modern Working Practices, Holman D, Wall TD, Clegg C, Sparrow P, Howard A (eds). Wiley: Chichester, UK; 311-328.

Wright PM, Gardner TM, Moynihan LM, Allen MR. 2005. The relationship between HR practices and firm performance: examining the causal order. Personnel Psychology 58(2): 409-446. 


\begin{tabular}{|c|c|c|c|c|c|}
\hline \multirow[b]{2}{*}{ Sector } & \multicolumn{5}{|c|}{ Company } \\
\hline & $\begin{array}{l}\text { Bank of America } \\
\text { Financials }\end{array}$ & $\begin{array}{c}\text { Microsoft } \\
\text { Information tech. }\end{array}$ & $\begin{array}{c}\text { Nike } \\
\text { Textiles \& apparel }\end{array}$ & $\begin{array}{l}\text { ExxonMobil } \\
\text { Energy }\end{array}$ & $\begin{array}{l}\text { Procter \& Gamble } \\
\text { Household products }\end{array}$ \\
\hline \multicolumn{6}{|l|}{ Community } \\
\hline Sector weight & $14.7 \%$ & $17.6 \%$ & $8.8 \%$ & $14.7 \%$ & $8.8 \%$ \\
\hline Score & 57.2 & 70.6 & 96.7 & 44.7 & 59.4 \\
\hline \multicolumn{6}{|l|}{ Customers } \\
\hline Sector weight & $14.7 \%$ & $11.8 \%$ & $8.8 \%$ & $5.9 \%$ & $11.8 \%$ \\
\hline Score & 22.9 & 52.5 & 64.2 & 45.5 & 44.3 \\
\hline \multicolumn{6}{|l|}{ Employees } \\
\hline Sector weight & $29.4 \%$ & $35.3 \%$ & $23.5 \%$ & $26.5 \%$ & $26.5 \%$ \\
\hline Score & 48.7 & 49.2 & 74.8 & 63.9 & 51.1 \\
\hline \multicolumn{6}{|l|}{ Environment } \\
\hline Sector weight & $35.3 \%$ & $23.5 \%$ & $35.3 \%$ & $47.1 \%$ & $47.1 \%$ \\
\hline Score & 52.6 & 43.3 & 61.6 & 29.3 & 39.2 \\
\hline \multicolumn{6}{|l|}{ Suppliers } \\
\hline Sector weight & $5.9 \%$ & $11.8 \%$ & $23.5 \%$ & $5.9 \%$ & $5.9 \%$ \\
\hline Score & 45.0 & 90.5 & 71.8 & 70.4 & 73.2 \\
\hline CRP index & 47.3 & 56.8 & 70.4 & 44.1 & 46.8 \\
\hline
\end{tabular}

\section{APPENDIX 2. MEASUREMENT ITEMS FOR INTANGIBLE RESOURCES}

\section{Human resources}

Job satisfaction

1) The degree of employee satisfaction in comparison with the industry average.

\section{Training programs}

2) The extent to which the company offers its employees training programs for improving their task efficiency.

\section{Profit sharing and participative programs}

3) The importance of employee shared-ownership plans.

4) The percentage of total workforce for which profit-sharing plans are in place.

5) The percentage of workers affected by participative management programs.

6) The percentage of workforce affected by indicators related to illness, accidents, fines/ penalties, and diversity.

\section{Information about employees}

7) A firm's commitment to achieving employee satisfaction through frequency of conducting satisfaction surveys by an external party.

Each item is ranked on a five-point Likert scale, where $0=$ non-existent; $1=$ below the median; $2=$ median level; $3=$ above the median; $4=$ maximum.

\section{Organizational culture}

Involvement: measures how organizations empower and engage their people, build teams, and develop human capability.

1) The degree of development of participative management programs. The extent to which the company has implemented programs such as an open-door policy, regular meetings between managers and employees, an employee commission, or a flat hierarchy.

Consistency: comprises the degree to which 1) organizations have a set of core values such as an ethical code that guides member behavior, 2) organizational members agree on critical issues and when they disagree the firm has mechanisms for reaching consensus, and 3 ) there is an alignment 
of goals across functions and units of the organization.

2) The degree of detail in the business ethic code of conduct.

3) The degree of detail in a system for collective dialogue with various stakeholders.

4) The company has a detailed code of conduct covering community, customers, employees, environment, and supplier issues.

Adaptability: the capability of the organization

1) to recognize the needs of customers and 2) to transform these needs into new products.

5) The degree of comprehensiveness and regularity of customer satisfaction surveys.

6) The degree to which stakeholders' issues are systematically taken into account by the $R \& D$ department in new product development.

Mission: identifies whether or not an organization has 1) a clear mission that gives meaning and direction to the work of its members and 2) clear policies to meet its objectives.

7) The company has a detailed written corporate statement that covers issues of stakeholders. That statement includes mission, vision, and values, and it is in place for at least 50 percent of operations.

8) The degree of development of a company's public reporting in its policies regarding stakeholders. A policy on stakeholder issues should have the following features: 1) applies company-wide or to at least 50 percent of total activity and 2) a formal written statement.

Each item is ranked on a five-point Likert scale, where $0=$ nonexistent; $1=$ below the median in detail and/or development; $2=$ median level; 3 $=$ above the median in detail and/or development; $4=$ maximum.

\section{APPENDIX 3. A TWO-STAGE ESTIMATION PROCEDURE}

The method outlined by Baron and Kenny (1986) requires the estimation of the following three regression models:

$$
\begin{aligned}
& \text { Intangible }_{i t}=\alpha^{1}+\beta_{C R P}^{1}(C R P)_{i t} \\
& \quad+\beta_{C F P}^{1}(C F P)_{i t}+\beta_{P R}^{1} \\
& \quad(\text { Physical resources })_{i t}+\beta_{L}^{1}(\text { Leverage })_{i t} \\
& \quad+\beta_{F R}^{1}(\text { Financial resources })_{i t}
\end{aligned}
$$

$$
\begin{aligned}
& +\beta_{S}^{1}(\text { Size })_{i t}+ \\
& +\beta_{\text {Risk }}^{1}(\text { Risk) })_{i t} \\
& \left.+\beta_{\text {mIntan }}^{1}(\text { Mean[Intangible }]\right)_{i t} \\
& +\left(\eta^{1}\right)_{i t}+\left(\varepsilon^{1}\right)_{i t} \\
& C F P_{i t}=\alpha^{2 A}+\beta_{C R P}^{2 A}(C R P)_{i t-1} \\
& +\beta_{P R}^{2 A}(\text { Physical resources })_{i t} \\
& +\beta_{L}^{2 A}(\text { Leverage })_{i t} \\
& +\beta_{F R}^{2 A}(\text { Financial resources })_{i t} \\
& +\beta_{S}^{2 A}(\text { Size })_{i t}+ \\
& +\beta_{\text {Risk }}^{2 A}(\text { Risk) })_{i t} \\
& +\beta_{m C F P}^{2 A}(\operatorname{Mean}[C F P])_{i t} \\
& +\left(\eta^{2 A}\right)_{i t}+\left(\varepsilon^{2 A}\right)_{i t} \\
& C F P_{i t}=\alpha^{3 A}+\beta_{C R P}^{3 A}(C R P)_{i t-1} \\
& +\beta_{I}^{3 A}(\text { Innovation })_{i t} \\
& +\beta_{H C}^{3 A}(\text { Human capital })_{i t} \\
& +\beta_{R}^{3 A}(\text { Reputation })_{i t} \\
& +\beta_{C}^{3 A}(\text { Culture })_{i t} \\
& +\beta_{P R}^{3 A}(\text { Physical resources })_{i t} \\
& +\beta_{L}^{3 A}(\text { Leverage })_{i t} \\
& +\beta_{F R}^{3 A}(\text { Financial resources })_{i t} \\
& +\beta_{S}^{3 A}(\text { Size })_{i t} \\
& +\beta_{\text {Risk }}^{3 A}(\text { Risk })_{i t} \\
& +\beta_{m C F P}^{3 A}(\operatorname{Mean}[C F P])_{i t} \\
& +\left(\eta^{3 A}\right)_{i t}+\left(\varepsilon^{3 A}\right)_{i t}
\end{aligned}
$$

where Mean[Intangible] and Mean[CFP] are the means of each intangible resource and CFP, respectively, for the corresponding sector, year, and country, and are calculated excluding the focal firm; $\eta$ is the fixed-effect term that approaches the time-invariant unobservable heterogeneity; and $\varepsilon$ is a random-noise residual. Importantly, as suggested in previous literature (e.g., Waddock and Graves, 1997a), CRP is lagged one period in order to tackle endogeneity problems, as explained in Footnote 6.

To establish mediation (Hypothesis 1a), three conditions must hold:

$$
\begin{aligned}
& \text { 1) } \beta_{C R P}^{1}>0 \text {; 2) } \beta_{C R P}^{2 A}>0 \text {; and 3) } \beta_{C R P}^{3 A}=0 \text {, } \\
& \text { while } \beta_{I}^{3 A}>0, \beta_{H C}^{3 A}>0 ; \beta_{R}^{3 A}>0 ; \beta_{C}^{3 A}>0
\end{aligned}
$$


Testing Hypothesis $1 \mathrm{~b}$ is formally equivalent to the above strategy, but replacing CRP by CFP and Mean $[C R P]$ by Mean $[C F P]$.

In estimating mediation models like ours, Baron and Kenny (1986) mentioned the emergence of an econometric problem with the estimates of the main independent variable and the mediator, as they are correlated by construction. This problem results in an overestimation of the effect of the main independent variable (CRP in Hypothesis 1a; CFP in Hypothesis 1b) and an underestimation of mediator variables in Models 3A and 3B. Baron and Kenney (1986: 1177) have suggested that some form of two-stage estimation or structural modeling procedure would provide a possible solution. Adopting this idea, we followed a two-stage procedure for refining the estimation of Models 3A and 3B. In the first stage of our procedure, we estimate two equations that correspond to the specifications given in Models $3 \mathrm{~A}$ and $3 \mathrm{~B}$, excluding the main independent variable:

$$
\begin{aligned}
& C F P_{i t}=\alpha^{4 A}+\beta_{I}^{4 A}(\text { Innovation })_{i t} \\
& \quad+\beta_{H C}^{4 A}(\text { Human capital })_{i t}+\beta_{R}^{4 A}(\text { Reputation })_{i t} \\
& +\beta_{C}^{4 A}(\text { Culture })_{i t}+\beta_{P R}^{4 A}(\text { Physical resources })_{i t} \\
& \quad+\beta_{L}^{4 A}(\text { Leverage })_{i t}+\quad(\text { Model 4A }) \\
& +\beta_{F R}^{4 A}(\text { Financial resources })_{i t}+\beta_{S}^{4 A}(\text { Size })_{i t} \\
& \quad+\beta_{R i s k}^{4 A}(\text { Risk })_{i t} \\
& +\beta_{m C F P}^{4 A}(\text { Mean }[\text { CF }])_{i t}+\left(\eta^{4 A}\right)_{i t}+\left(\varepsilon^{4 A}\right)_{i t} \\
& C R P_{i t}=\alpha^{4 B}+\beta_{I}^{4 B}(\text { Innovation })_{i t}+\beta_{H C}^{4 B}
\end{aligned}
$$

$(\text { Human capital })_{i t}+\beta_{R}^{4 B}(\text { Reputation })_{i t}$ $+\beta_{C}^{4 B}(\text { Culture })_{i t}+\beta_{P R}^{4 B}(\text { Physical resources })_{i t}$ $+\beta_{L}^{4 B}(\text { Leverage })_{i t}+$

(Model 4B)

$$
\begin{aligned}
& +\beta_{F R}^{4 B}(\text { Financial resources })_{i t} \\
& +\beta_{S}^{4 B}(\text { Size })_{i t}+\beta_{\text {Risk }}^{4 B}(\text { Risk })_{i t} \\
& +\beta_{m C R P}^{4 B}(\text { Mean }[C R P])_{i t}+\left(\eta^{4 B}\right)_{i t}+\left(\varepsilon^{4 B}\right)_{i t}
\end{aligned}
$$

With such coefficients, we compute the following instruments as the part of the performance that is not explained by the intangible resources:

Residual CF $P_{i t}=C F P_{i t}-\left[\beta_{I}^{4 A}(\text { Innovation })_{i t}\right.$

$+\beta_{H C}^{4 A}(\text { Human capital })_{i t}+\beta_{R}^{4 A}(\text { Reputation })_{i t}$ $\left.+\beta_{C}^{4 A}(\text { Culture })_{i t}\right]$

Residual $C R P_{i t}=C R P_{i t}-\left[\beta_{I}^{4 B}(\text { Innovation })_{i t}\right.$

$+\beta_{H C}^{4 B}(\text { Human capital })_{i t}+\beta_{R}^{4 B}(\text { Reputation })_{i t}$ $\left.+\beta_{C}^{4 B}(\text { Culture })_{i t}\right]$

In the second stage, we replace CRP and CFP of Models 3A and 3B with their instrumentsResidual CFP and Residual CRP, respectivelywhich, as explained in the main text, are also lagged by one period to prevent reverse causality problems. Resulting models are denoted as $3 \mathrm{~A}^{*}$ and $3 \mathrm{~B}^{*}$. If we denote as $\beta^{3 A^{*}}$ and $\beta^{3 B^{*}}$ the new coefficients estimated in the second-stage estimation of Models $3 \mathrm{~A}^{*}$ and $3 \mathrm{~B}^{*}$, our mediation Hypothesis 1a holds if the three conditions defined above are satisfied by using $\beta^{3 A^{*}}$ instead of $\beta^{3 A}$ in the third condition. Similarly, to prove the mediation of intangibles in the relationship from CFP to CRP, our Hypothesis $1 \mathrm{~b}$, the corresponding three conditions defined above must hold, using $\beta^{3 B^{*}}$ rather than $\beta^{3 B}$ in the third condition. 